\title{
Consideraciones sobre los principios del derecho administrativo y su vigencia y aplicación en el ámbito urbanístico ${ }^{1}$
}

\author{
M anuel M oreno Linde
}

Doctor en Derecho.

Profesor Colaborador de Derecho Administrativo.

Universidad de Málaga

\begin{abstract}
SUMARIO: I. INTRODUCGIÓN. II. LOS PRINCIPIOS GENERALES DEL DERECHO ADMINISTRATIVO. NOTAS GARACTERÍSTICAS Y FUNGIONES. 1. Los principios generales del derecho. Naturaleza y características. Su importancia para el Derecho Administrativo. 2. Las funciones de los principios generales del derecho. III. VIGENGIA Y APLICACIÓN DE LOS PRINGIPIOS EN EL URBANISMO. 1. Principios jurídicos con incidencia en la función urbanística. Análisis sucinto. A. Principio de proporcionalidad. B. Principios de igualdad y de interdicción de la arbitrariedad. C. Principios de seguridad jurídica, buena fe y confianza legítima. D. Principio de desarrollo urbano sostenible. 2. Incidencia de estos principios en el ejercicio de las potestades urbanísticas. A. Planeamiento y gestión urbanística. B. Disciplina urbanística. IV. REFLEXIONES FINALES. V. BIBLIOGRAFÍA.
\end{abstract}

\section{RESUMEN:}

Los principios jurídicos son un elemento fundamental del ordenamiento jurídico, en la medida en que dotan de coherencia y estabilidad al conjunto de elementos diversos que lo integran. Con esta idea como base, el presente trabajo tiene por objeto la formulación de algunas consideraciones en torno a los principios del Derecho Administrativo, en general, y de manera particular sobre su incidencia en el campo más específico del Derecho Urbanístico, un sector en el que,

\footnotetext{
${ }^{1}$ El presente trabajo es fruto de la reflexión bien documentada de algunas de las ideas que sobre este tema están recogidas en nuestra Tesis Doctoral, defendida en la Universidad de Málaga el 13 de diciembre de 2013.
} 
a nuestro parecer, resulta especialmente necesario reivindicar el papel de los principios por la proliferación en él de soluciones creadas ad hoc, coyunturales y a menudo provisionales, que, por apartarse de aquéllos, terminan resultando insatisfactorias.

PALABRAS CLAVE:

Principios, Derecho Administrativo, Urbanismo, Potestades Administrativas.

\section{ABSTRACT:}

The legal principles are an essential element of the legal system to the extent that give coherence and stability to the ensemble of the different elements that define it. Based on that idea, this current article is aimed to formulate some considerations about the Administrative Law Principles, in general, and particularly about its impact in the more specific field of the Urban Law. We consider that it is necessary, especially in this sector, to reclaim the role of the principles owing to the increase of arrangements which become unsatisfactory because they have been created separated from the principles, circumstantially and often temporary.

KEY WORDS:

Principles of Law, Administrative Law, Urban Planning, Administrative Powers.

\section{INTRODUGGIÓN}

Los principios jurídicos son elementos capitales del ordenamiento jurídico, los instrumentos que expresan los valores éticos y políticos que presiden sus elementos positivos y que conectan a sus instituciones. Esa función es especialmente trascendente en un sector del Derecho como el Administrativo, caracterizado por una actividad normativa incesante, y en el que, en consecuencia, existen un elevadísimo número de normas que precisan especialmente de principios que doten a todo ese conjunto de una mínima estabilidad y seguridad.

Los principios constituyen verdaderas prescripciones jurídicas que obligan, aunque sea de forma indirecta, a la Comunidad. Ciertamente, se asiste actualmente a un desprestigio de estos instrumentos jurídicos, motivado en buena medida por el uso abusivo y meramente retórico que se da a los mismos. Pero los principios siguen plenamente vigentes y deben seguir presidiendo, en cuanto expresivos del acervo cultural-jurídico de la Comunidad, la labor de creación y aplicación del Derecho. 
Estas consideraciones y las que se harán a continuación se formulan al hilo del análisis de un ámbito concreto del Derecho Público, el urbanístico, en relación con el cual han de reivindicarse especialmente los principios jurídicos, a la vista de la proliferación en el mismo de soluciones deslavazadas e intrincadas, caracterizadas frecuentemente por su provisionalidad y excesiva orientación a intereses específicos; soluciones que, por alejadas de aquellos principios, resultan insatisfactorias.

Este es el punto de partida del presente trabajo, en el que se abordará, en primer término, el estudio de los principios del Derecho Administrativo, sus características y funciones, para a continuación examinar su alcance e incidencia en el Derecho Urbanístico.

\section{LOS PRINCIPIOS GENERALES DEL DEREGHO ADMINIS- TRATIVO. NOTAS GARAGTERÍSTICAS Y FUNGIONES}

En el presente apartado se expondrán una serie de consideraciones sobre la naturaleza y características de los principios jurídicos, su importancia para el Derecho Administrativo y las funciones que desempeñan en este sector del ordenamiento jurídico.

\section{Los principios generales del derecho. Naturaleza y caracterís- ticas. Su importancia para el Derecho Administrativo}

En palabras de REBOLLO PUIG, los principios generales del derecho son las ideas directrices de un ordenamiento jurídico, las que inspiran, orientan, relacionan y estructuran sus distintos elementos, normativos y no normativos. Son, como gráficamente señala este autor, las reglas que permiten encajar todas las piezas del complejo rompecabezas en que consiste el ordenamiento jurídico². Así, los principios generales del derecho, al expresar los valores materiales básicos del ordenamiento jurídico, aquellos sobre los que se constituyen las convicciones ético-jurídicas de una Comunidad ${ }^{3}$, dotan de sentido y funcionalidad a todos sus elementos, confiriendo de esa forma a éste su coherencia y unidad.

\footnotetext{
${ }^{2}$ REBOLLO PUIG, Manuel (2010): "Los principios generales del derecho (atrevimiento atribulado sobre su concepto, funciones e inducción)" en la obra colectiva "Los principios jurídicos del Derecho Administrativo", 1ª ed., La Ley, Madrid, págs. 1.525-1.527

${ }^{3}$ GARCÍA DE ENTERRÍA, Eduardo y FERNÁNDEZ, Tomás-Ramón (2006): “Curso de Derecho Administrativo, I", $13^{\text {a }}$ ed. Thomson-Civitas, Madrid, pág. 85.
} 
La trascendencia del papel que los principios del derecho juegan en el ordenamiento jurídico administrativo, del que se suele decir que es predominantemente principal ${ }^{4}$, es reconocida hoy de forma unánime por la doctrina. Las razones de este papel predominante de los principios jurídicos en el Derecho Administrativo han sido expuestas, entre otros autores, por GARCÍA DE ENTERRÍA ${ }^{5}$.

La primera razón se encuentra en el propio carácter del ordenamiento jurídico-administrativo, tan dado a la producción normativa contingente y ocasional -"legislación motorizada"- imposible de ser seguida por el jurista, y en el que abundan las denominadas Leyes-Medida, expresiones de una voluntad ordenada a un fin político concreto que, en la búsqueda del objetivo propuesto, prescinden de toda referencia a los valores de justicia. Todo ello determina la necesidad de contar con un sistema firme de principios generales con el que adentrarse en ese complejo entresijo de normas administrativas y enfrentarse con seguridad a todas las situaciones que el mismo vaya planteando.

A esta primera razón añade otras. En primer lugar, señala la posibilidad de que la Administración, en cuanto capacitada para producir normas jurídicas, pueda tratar de hacer valer en las mismas sus propios intereses. Frente a este riesgo, los principios jurídicos actúan como mecanismos de control que permiten, desde la perspectiva de la justicia, evitar o, al menos, reducir los excesos burocráticos ${ }^{6}$.

${ }^{4}$ REBOLLO PUIG, Manuel (2010): 1.544. En relación con esta afirmación, vid. GARCíA DE ENTERRÍA, Eduardo (1963a): "Reflexiones sobre la Ley y los principios generales del Derecho en el Derecho Administrativo", publicado en Revista de Administración Pública 40, y en "Reflexiones sobre la Ley y los principios generales del Derecho" Cuadernos Cívitas, Madrid, págs. 42-43, en las que el autor sostiene que los principios generales del derecho constituyen la base del nacimiento del propio Derecho Administrativo. En el mismo sentido, GARCÍA DE ENTERRÍA, Eduardo y FERNÁNDEZ, Tomás-Ramón (2006): 90.

En la misma línea, RODRÍGUEZ-ARANA MUÑOZ afirma que "el Derecho Administrativo es una elaboración operada casi exclusivamente a partir de principios generales, en torno a los cuales ha ido cerrándose una tupida y extensa red de principios y reglas secundarias que han terminado por formar un sistema" (RODRÍGUEZARANA MUÑOZ, Jaime (2008): "Los principios generales del Derecho Administrativo en la jurisprudencia administrativa española", Revista andaluza de Administración Pública 70, pág. 46).

${ }^{5}$ Sobre las razones de la especial relevancia de los principios generales del derecho en el Derecho Administrativo, vid. GARCÍA DE ENTERRÍA, Eduardo (1963a): 39-41 y GARCÍA DE ENTERRÍA, Eduardo y FERNÁNDEZ, Tomás-Ramón (2006): 87-88.

${ }^{6}$ A este respecto, se ha llegado a afirmar que "su carácter inspirador del Ordenamiento nos lleva a reconocer en los principios las guías, los faros, los puntos de referencia necesarios para que, en efecto, el Derecho Administrativo no se convierta en una maquinaria de producción normativa al servicio del poder sin más asideros que las normas escritas y las costumbres que puedan ser de aplicación en su defecto" (RODRÍGUEZ-ARANA MUÑOZ, Jaime (2008): 39). 
Por último, en relación con la discrecionalidad administrativa, los principios generales del derecho constituyen el necesario parámetro de control del margen de maniobra que las leyes atribuyen a la Administración en el ejercicio de la potestad discrecional, evitando que esa libertad se convierta en arbitrariedad.

Así pues, no cabe duda de que los principios jurídicos constituyen un elemento nuclear del Derecho Administrativo, en cuanto que son los instrumentos que garantizan la racionalidad, la seguridad y la justicia de este ordenamiento. No obstante, el entusiasmo que despierta el reconocimiento de su valor a los principios generales del derecho no debe conducir, como ha señalado un sector de la doctrina, a un uso abusivo de los mismos ${ }^{7}$.

Centrándonos ahora en las notas características de los principios generales del derecho, en primer lugar, para GARCÍA DE ENTERRÍA, la expresión "principios" permite advertir que se trata de verdaderos principios en sentido ontológi$\mathrm{co}^{8}$ y no de meras reglas heurísticas, opinión que parece compartir LEGUINA ${ }^{9}$. Desde este punto de vista, los principios forman parte estructural del ordenamiento como realidad, no son meros criterios interpretativos. Esta cuestión, no obstante, no es totalmente pacífica en la doctrina ${ }^{10}$.

${ }^{7}$ A este respecto, especialmente crítico se ha mostrado recientemente SANTAMARÍA PASTOR con el uso excesivo que se viene dando a los principios jurídicos, en lo que él denomina como una " $a u^{-}$ téntica orgía principalista”. Según el autor, este abuso consiste, de una parte, en la creciente inclinación del legislador a insertar en las normas, de manera formal, los principios inspiradores de la legislación sectorial de que se trate, práctica ésta que vacía parcialmente de contenido prescriptivo a las normas jurídicas y que además introduce un considerable factor de inseguridad en su aplicación. De otra parte, rechaza la tendencia de los juristas del Derecho Público a proponer como soluciones interpretativas de determinados preceptos, al amparo de los principios generales del derecho, reglas abiertamente contradictorias con su texto, ofreciendo una versión ideal del derecho vigente o de la jurisprudencia que nada tiene que ver con la realidad, manifiestamente discordante con ella (vid. SANTAMARÍA PASTOR, Juan Alfonso (2010) Presentación de la obra colectiva "Los principios jurídicos del Derecho Administrativo" $1^{a}$ ed., La Ley, Madrid, págs. 49-52). En la misma línea se han expresado NIETO (NIETO GARCÍA, Alejandro (2005): "Derecho Administrativo Sancionador", $4^{a}$ ed., Tecnos, Madrid, pág. 43) y ARANA GARCÍA (ARANA GARCÍA, Estanislao (2003): La alegación de la propia torpeza y su aplicación al Derecho Administrativo, Editorial Comares, Granada, págs. 9-10).

${ }^{8}$ GARCÍA DE ENTERRÍA, Eduardo (1963b). "Prólogo al libro de Theodor Viehweg «Tópica y Jurisprudencia»", publicado en la Revista de Administración Pública 40 y en su libro "Reflexiones sobre la Ley y los principios generales del Derecho", Cuadernos Cívitas, Madrid, pág. 79 y GARCÍA DE ENTERRÍA, Eduardo y FERNÁNDEZ, Tomás Ramón (2006): 85.

${ }^{9}$ LEGUINA VILLA, Jesús (1987): "Principios generales del Derecho y Constitución”, Revista de Administración Pública 114, pág. 10.

${ }^{10}$ MARTÍN REBOLLO, aunque entiende que la discusión sobre la naturaleza ontológica o hermenéutica de los principios generales del derecho no constituye una dicotomía excluyente, sino 
En segundo lugar, son principios generales, en cuanto que trascienden a preceptos concretos ${ }^{11}$. Precisamente por ello sirven de soportes primarios estructurales del sistema entero del ordenamiento. Es decir, si dotan a todo el ordenamiento de coherencia y unidad es precisamente porque, al ser generales, trascienden a sus elementos singulares.

Por último, son principios jurídicos, esto es, pertenecen al Derecho. A este respecto, se ha señalado que son jurídicos por la realidad a la que se refieren e inspiran y por su propio contenido. No son meros criterios filosóficos, morales o religiosos, aunque a veces puedan coincidir con ellos ${ }^{12}$. Y sentada su pertenencia al Derecho, los principios generales se integran en el ordenamiento jurídico, forman parte de él, no son reglas previas extrasistema, aunque desde algún sector doctrinal se haya sostenido lo contrario ${ }^{13}$. Sobre la inclusión de los principios en el ordenamiento, LEGUINA ha señalado que entre éstos y las normas stricto sensu no hay diferencia de naturaleza: ambos tipos de preceptos forman parte del ordenamiento jurídico y son, por ello, en igual medida, derecho objetivo, aunque difieran en cuanto a su estructura, funciones y posición dentro del mismo ${ }^{14}$. Precisamente de estas últimas cuestiones - funciones de los principios y posición dentro del ordenamiento- se ocupa el siguiente apartado.

que se trata más de una cuestión de perspectiva, afirma que si tiene que elegir, se inclina por considerar que los principios juegan más en el ámbito de la hermenéutica (MARTÍN REBOLLO, Luis (2010): "Sobre los principios generales del derecho. Una reflexión moderadamente crítica" en la obra colectiva "Los principios jurídicos del Derecho Administrativo", 1ª ed., La Ley, Madrid, pág. 1513.

${ }^{11}$ GARCÍA DE ENTERRÍA, Eduardo. y FERNÁNDEZ, Tomás-Ramón (2006): 85.

12 REBOLLO PUIG, Manuel (2010): 1.525-1.526. En el mismo sentido GARCíA DE ENTERRÍA y TOMÁS-RAMÓN FERNÁNDEZ afirman que los principios generales del derecho "son fórmulas técnicas del mundo jurídico y no simples criterios morales, o menos aún, las famosas buenas intenciones o vagas o imprecisas directivas" (GARCÍA DE ENTERRÍA, Eduardo. y FERNÁNDEZ, Tomás-Ramón (2006): 85).

${ }^{13}$ En este sentido, RODRÍGUEZ-ARANA MUÑOZ sostiene que los principios generales del derecho "existen por si mismos porque son la proyección en la realidad jurídica de la esencial idea de justicia que trasciende al Ordenamiento Furídico y le da sentido. Desde este punto de vista, los principios son previos al Ordenamiento" (RODRÍGUEZ-ARANA MUÑOZ, Jaime (2008): 40 y 41).

${ }^{14}$ LEGUINA VILLA, Jesús (1987): 10. En esta línea, REBOLLO PUIG afirma, partiendo de una de las acepciones de la palabra principio del Diccionario de la Real Academia de la Lengua Española -los principios entran en la composición del cuerpo- que "eso es también lo que sucede con los principios generales del derecho: forman parte del ordenamiento jurídico como los principios de una lengua forman parte de ella" (REBOLLO PUIG, Manuel (2010): 1.525). Por último, SUAY RINCÓN considera que el hecho de que el artículo 1.1 del C.c. incluya entre las fuentes del derecho a los principios generales del derecho, sitúa a éstos dentro del ordenamiento jurídico. Con ello, sostiene el autor, se resuelve la vieja 


\section{Las funciones de los principios generales del derecho}

La doctrina suele reconocer tres funciones esenciales a los principios generales del derecho: la función informadora, la interpretativa o hermenéutica (ésta podría entenderse incluida en la primera) y la de fuente supletoria del derecho ${ }^{15}$ Estas funciones se pueden deducir hoy del tenor literal del artículo 1.4 del C.c., según el cual "los principios generales del derecho se aplicarán en defecto de Ley y costumbre, sin perjuicio de su carácter informador del ordenamiento jurídico."

Así, en primer término, los principios generales del derecho cumplen el cometido de inspirar, orientar o informar los elementos normativos y los no normativos del ordenamiento jurídico ${ }^{16}$. Esta función no depende de que las normas positivas la reconozcan, porque es consustancial al propio concepto y naturaleza de los principios. A este respecto, el Tribunal Supremo ha señalado que "los principios generales del derecho, esencia del ordenamiento jurídico, son la atmósfera en la que se desarrolla la vida jurídica, el oxígeno que respiran las normas, lo que explica que sinformens las normas $" 17$ Desde esta perspectiva, los principios se conciben como auténticas guías del sistema jurídico, elementos basilares del mismo que sostienen y dan vida a las normas. Son elementos inspiradores, criterios sobre los que se debe edificar el Derecho Administrativo. ${ }^{18}$

Debe indicarse, no obstante, que la función informadora de los principios generales no entraña un mandato para los poderes públicos cuyo incumplimiento

polémica doctrinal sobre la naturaleza de los principios (iusnaturalismo v. positivismo): los principios generales del derecho son derecho positivo, y no algo ajeno, exterior o trascedente (SUAY RINCÓN, José (1993): "La doctrina de los principios generales del derecho y su contribución al desarrollo del Derecho Administrativo" en la obra colectiva "La protección jurídica del ciudadano (Procedimiento administrativo y garantía jurisdiccional). Estudios en homenaje al profesor Jesús González Pérez, I", 1ª ed. Civitas, Madrid, pág. 384.

${ }^{15}$ Así, por ejemplo, ORTEGA ÁLVAREZ señala que los principios actuarían de una triple forma: "En primer lugar, como reflejo de valores sociales consagrados que actúan como guía del agente productor de otras fuentes del derecho, como la Ley o el reglamento. En segundo término, como regla interpretativa de estas mismas fuentes a las que se incorpora formando parte de ellas. Finalmente, actúan como fuente subsidiaria de la Ley y la costumbre, en cuyo cometido, tal y como señala la exposición de motivos del decreto de 31 de mayo de 1974, por el que se aprueba el Texto articulado del Título preliminar del Código Civil, son los únicos que cumplen la función autónoma de fuente del derecho" (ORTEGA ÁLVAREZ, Luis (2002): "Los principios generales del derecho" en la obra colectiva "Derecho Administrativo I: Introducción y Ordenamiento Jurídico", $1^{a}$ edición, Iustel, edición digital, Madrid).

${ }^{16}$ REBOLLO PUIG, Manuel (2010): 1.545

${ }^{17}$ STS de 16 de mayo de 1990 (RJ 1990/4167).

${ }^{18}$ RODRÍGUEZ-ARANA MUÑOZ, Jaime (2008): 40. 
comporte alguna consecuencia jurídica. En este sentido, desde la perspectiva de la función informadora de los principios, el legislador, por ejemplo, no tendría necesariamente que respetar un principio preexistente, y ello -la vulneración del principio- no traería consigo la invalidez de la norma. Cuestión distinta son los límites que vengan impuestos al legislador por los principios en función de la consideración que éstos merezcan como fuentes del derecho ${ }^{19}$.

Esta segunda función -la de fuente del Derecho- al contrario que la informadora, no es consustancial a los principios generales del derecho. Ello quiere decir que el legislador podría haber optado por no incluir a los principios entre las fuentes del derecho, articulando otras soluciones para cubrir las lagunas normativas, o, al contrario, haberle otorgado un valor superior al de mera fuente supletoria $^{20}$.

A este respecto, la realidad es que los principios generales, como fuente del derecho, no cumplen hoy la función meramente supletoria que le confía el artículo 1.4 del C.c. Ello, debido al proceso de positivación de los principios en normas escritas que se viene produciendo en los últimos años, que comporta la asunción por aquéllos del valor y eficacia propios de la fuente formal que los acoge $\mathrm{e}^{21}$.

Pero dejando al margen este fenómeno de la positivación de los principios, lo cierto es que la posición de fuente supletoria que les atribuye el artículo 1.4 del C.c. admite algunas matizaciones.

En primer lugar, la doctrina viene sosteniendo la superioridad jerárquica de los principios sobre los reglamentos -a los que no hace referencia el referido artículo 1.4 C.c.- algo que, como apunta SUAY RINCÓN, ya fue afirmado por nuestro Tribunal Supremo en sendas sentencias de 20 de febrero y 6 de julio de

19 Esta opinión es mantenida por REBOLLO PUIG, quien reconoce que las normas pueden tener límites que eventualmente coincidan con el contenido de los principios generales del Derecho, si bien esos límites no derivan de un mandato según el cual los principios generales ya consolidados deban informar las normas, de que éstos deban respetarlos, sino del valor de cada una de esas normas (la que expresa el principio y la que lo vulnera o excepciona) y de su respectiva posición en el ordenamiento (REBOLLO PUIG, Manuel (2010): 1.546). En la misma línea, ORTEGA ÁLVAREZ ha sostenido que "un principio del que se pretenda una mera función informadora, si no es recogido en la Constitución, no puede actuar como parámetro jurídico de la legitimidad de una Ley" (ORTEGA ÁLVAREZ, Luis (2002).

${ }^{20}$ REBOLLO PUIG, Manuel (2010): 1.550.

${ }^{21}$ En este sentido, SUAY RINCÓN, José (1993): 385, y ORTEGA ÁLVAREZ, Luis (2002). 
$1959^{22}$. Esta consideración parece ser corroborada por el contenido del artículo 103.1 de la CE, en el que se afirma que la Administración Pública actúa -también su potestad reglamentaria- "con pleno sometimiento a la Ley y el Derecho", expresión con la que se quiere poner de manifiesto que existe un Derecho distinto de la Ley escrita, en el que, sin duda, están incluidos los principios generales del derecho ${ }^{23}$, al que también está sujeta la Administración.

Sentado el valor suprarreglamentario de los principios como fuentes del derecho, parece razonable situarlos en la escala jerárquica por debajo de la Ley. Ello resulta coherente, además de con el tenor del artículo 1.4 del G.c., con la idea de seguridad jurídica, ya que la Ley constituye una expresión de la voluntad popular más inequívoca y tangible que la que pueda contenerse en un principio general del derecho no positivado ${ }^{24}$.

${ }^{22}$ Según señala SUAY RINCÓN, en la primera de las sentencias se considera que la extensión de las obligaciones docentes de los catedráticos de enseñanza fuera de su propias materias era contrario al principio de la «naturaleza del cargo»; la segunda aplicó el principio de igualdad en el funcionamiento de los servicios públicos para resolver la adjudicación de un partido veterinario en la provincia de Jaén (SUAY RINCÓN, José (1993): 386).

${ }^{23}$ A este respecto, GARCÍA DE ENTERRÍA y TOMÁS-RAMÓN FERNÁNDEZ sostienen que "el artículo 103.1 de la Constitución, que declara el sometimiento pleno a la Ley y al derecho de la Administración constitucionaliza resueltamente esa idea básica de que no sólo la legalidad escrita vincula de una manera positiva la acción -cualquier acción: plenitud del sometimiento de los poderes administrativos de cualquier orden; el Derecho, como distinto de la Ley, es aqui el fondo material de justicia que expresan los principios generales y sublegales y que es siempre inexcusable aplicar en la relación Administración-ciudadanos como fundamento mismo del orden político (art. 10.1 de la Constitución)" (GARCÍA DE ENTERRÍA, Eduardo y FERNÁNDEZ, Tomás-Ramón (2006): 90 y 91). En similar sentido, GARCÍA DE ENTERRÍA, Eduardo (1984): "Principio de legalidad, Estado material de derecho y facultades interpretativas y constructivas de la jurisprudencia en la Constitución", publicado en la Revista Española de Derecho Constitucional 10 y en su libro "Reflexiones sobre la Ley y los principios generales del Derecho", Cuadernos Civitas, Madrid, págs. 92 y ss.

${ }^{24}$ A este respecto, ORTEGA ÁLVAREZ, que sostiene la prevalencia de la Ley sobre los principios generales como fuentes del derecho, apunta el problema de inseguridad jurídica que plantea la entrada en vigor de un principio general del derecho, pues, a su juicio "las referencias doctrinales como la de BELADÍEZ que prescriben la obligatoriedad de los principios «desde que se integran en la conciencia colectiva), no resuelven la determinación del momento en que la conciencia colectiva asume tal integración" (ORTEGA ÁLVAREZ, Luis (2002). A este respecto, la propia BELADÍEZ reconoce la dificultad que entraña la prueba de la integración de un principio en la conciencia colectiva. Así, señala esta autora que "no se puede determinar el momento justo en el que algo es sentido como valioso por la colectividad, igual que tampoco se puede concretar el momento exacto en que esa idea ha dejado de ser considerada como un valor por esa misma sociedad. La única forma de demostrar la vigencia social de un valor o, lo que es lo mismo, la existencia de un principio es mediante su propia aplicación" (BELADÍEZ ROJO, Margarita (1994): "Los principios jurídicos", $1^{\text {a }}$ edición, Tecnos, Madrid, págs. 55 y 56). 
Por último, en lo que respecta a la costumbre como fuente del derecho, es dificil considerar, pese al tenor del artículo 1.4 del C.c., que ésta pueda anteponerse a los principios generales del derecho, habida cuenta del carácter estructurante del ordenamiento jurídico que se ha atribuido a los mismos. En este sentido, si, de una parte, tal y como señala el artículo 1.3 del C.c., la costumbre no puede ser contraria a la moral ni al orden público, y, de otra, los principios generales del derecho vienen a ser precisamente la expresión de los valores materiales básicos del ordenamiento jurídico, las convicciones ético-jurídicas fundamentales de una Comunidad, resulta inimaginable que la costumbre pueda contravenir un principio general del derecho ${ }^{25}$

La tercera función de los principios de las antes referidas - aunque puede considerarse incluida dentro de la informativa- es la hermenéutica o interpretativa. Se trata, ésta, de otra función consustancial a la propia naturaleza de los principios, pues, si como se acaba de decir, los principios expresan los valores ético-jurídicos de la sociedad y, consecuentemente, estructuran y dan sentido al ordenamiento jurídico, es evidente que sus elementos normativos han de ser interpretados de conformidad con ellos. Así pues, como ha señalado GARCÍA DE ENTERRÍA, los principios generales del derecho presiden la interpretación de las fuentes escritas. ${ }^{26}$

De este modo, puede sostenerse que la interpretación de cada norma consiste precisamente en buscar el sentido más adecuado a los principios generales del derecho. Así, los principios sirven de criterio para determinar si debe realizarse una interpretación extensiva o restrictiva de la norma, o si, dado el tenor de un precepto, hay que inclinarse por el criterio de interpretación literal, sistemático o cualquier otro. ${ }^{27}$ En definitiva, sólo desde los principios generales del derecho puede asegurarse una interpretación de las normas que vaya más allá de la estática voluntad del legislador y resulte coherente con los valores que en cada momento sustenten el ordenamiento jurídico.

${ }^{25}$ En cuanto a la prevalencia de los principios generales del derecho sobre la costumbre, vid. ORTEGA ÁLVAREZ, Luis (2002).

${ }^{26}$ GARCÍA DE ENTERRÍA, Eduardo y FERNÁNDEZ, Tomás-Ramón (2006): 91. GARCÍA DE ENTERRÍA ha destacado el papel que como elementos de interpretación del ordenamiento jurídico cumplen los principios generales del derecho. Así, el autor reconoce, siguiendo a GÉNY, que el intérprete del derecho debe manejar datos y criterios prepositivos para poder descender al examen mismo de los elementos positivos. Estos datos prepositivos se hallan en los principios generales del derecho, de los que no cabe prescindir en la elección de los criterios interpretativos de las normas (sistemático, gramatical, analógico etc.) por ser los únicos elementos disponibles para dar sentido a las instituciones y para articular éstas en el sistema general del ordenamiento (GARCíA DE ENTERRÍA, Eduardo (1963a): 19 y ss).

${ }^{27}$ Vid. REBOLLO PUIG, Manuel (2010): 1.547 y 1.548. 
Para concluir esta exposición sobre las funciones de los principios generales del derecho, ha de hacerse referencia a una función que cumplen los principios, específicamente, en el ámbito jurídico-administrativo: la de habilitar y limitar el ejercicio de las potestades administrativas.

El correcto entendimiento de la función de habilitación de potestades administrativas, requiere la comprensión de una premisa conceptual: la Administración únicamente puede actuar en virtud de las habilitaciones que reciba del ordenamiento jurídico, en virtud de una potestad administrativa que éste le confiera. Tal aseveración viene a identificar lo que MERKL enunció como principio de juricidad, según el cual toda acción administrativa aislada está condicionada por la existencia de un precepto administrativo que admite semejante acción ${ }^{28}$.

Tomando como referencia esta idea de que toda actuación administrativa supone el ejercicio de una potestad previamente atribuida por el ordenamiento jurídico, se trata ahora de determinar si esa atribución puede proceder de los principios generales del derecho. Y a este respecto, cabe considerar que, de alguna forma, determinados principios generales del derecho pueden cumplir una función habilitadora de actuaciones administrativas. Sin embargo, en la mayor parte de los casos, la habilitación que confiere el principio será tan genérica que requerirá de un instrumento intermedio que permita su efectiva materialización; instrumento que será el que atribuya la potestad concreta al amparo de la cual el órgano administrativo ejecutará su acción.

No obstante, lo anterior no excluye que ocasionalmente puedan los principios generales del derecho conferir directamente a la Administración una habilitación para adoptar un concreto comportamiento. En este sentido, se ha señalado que puede ser un principio general el que, al margen de toda autorización legal, habilite a la Administración, en situaciones de necesidad, para adoptar todas las medidas que sean precisas, incluso restrictivas de la libertad ${ }^{29}$.

${ }^{28} \mathrm{El}$ principio fue enunciado por el MERKL en su Teoría general del Derecho Administrativo. A este respecto, vid. REBOLLO PUIG, Manuel (1991) "Juricidad, legalidad y reserva de Ley como límites de la potestad reglamentaria”, Revista de Administración Pública 125, págs. 93-101 y BELADÍEZ ROJO, Margarita (2000) "La vinculación de la Administración al Derecho", Revista de Administración Pública 153, págs. 315-349.

${ }^{29}$ REBOLLO PUIG, Manuel (2010): 1.562. El autor cita otro ejemplo "desde un plano más modesto" de supuestos en los que la Administración actúa bajo la cobertura exclusiva de un principio general del derecho. Se trata de la posibilidad, admitida por los tribunales, de que la Administración, al amparo del principio del enriquecimiento injusto, dicte -y ejecute- un acto administrativo para reclamar del enriquecido la restitución del valor del incremento patrimonial injusto. 
Por otra parte, los principios generales del derecho cumplen la función de servir de limitación -o delimitación- de las potestades administrativas. Tal función es corolario lógico de otras que se han expuesto con anterioridad. Así, de una parte, desde la perspectiva de la función informadora y hermenéutica de los principios, si éstos inspiran la norma habilitante que atribuye una potestad a la Administración y presiden su interpretación, es claro que esa potestad ha de actuarse conforme a las exigencias de esos principios ${ }^{30}$. Y de otra, no puede olvidarse que conforme a lo expuesto anteriormente, los principios generales son fuente del derecho al que se sujeta la Administración. Por tanto, la Administración está obligada a modular el ejercicio de sus potestades en función de los principios generales del derecho.

Esta función de limitación de los principios es especialmente relevante en el ejercicio de las potestades discrecionales, que dotan a la Administración, según cada caso, de un mayor o menor margen de maniobra para adoptar la decisión que estime más oportuna. Sobre ello se volverá en el siguiente apartado, en el que se analizará, entre otras cuestiones, la incidencia de los principios jurídicos en el ejercicio de una potestad profundamente discrecional, como es la de planificación urbanística.

\section{VIGENGIA Y APLICAGIÓN DE LOS PRINGIPIOS EN EL URBANISMO}

Una vez examinadas las características y las funciones de los principios generales del Derecho Administrativo, en las próximas páginas se analizará su incidencia en la acción urbanística. Así, en primer lugar se realizará un estudio sucinto de algunos principios jurídicos - particularmente de los de mayor trascendencia en el ejercicio de las potestades urbanísticas- y en segundo lugar se abordará de forma concreta su repercusión en los tres ámbitos fundamentales del Derecho Urbanístico: planeamiento, gestión y disciplina urbanística.

\section{Principios jurídicos con incidencia en la función urbanística. Análisis sucinto}

El ejercicio de las potestades administrativas se ve informado por multitud de principios generales que ordenan o deberían ordenar el actuar de la Administración. De todos ellos, en este punto van a ser estudiados aquellos que, a nuestro parecer, tienen mayor incidencia en el ejercicio de las potestades urbanísticas. Algu-

${ }^{30}$ STS de 16 de mayo de 1990 (RJ 1990/4167). 
nos de ellos son principios de indudable tradición en nuestro Derecho, concretamente los de proporcionalidad, igualdad, interdicción de la arbitrariedad y seguridad jurídica (y sus corolarios, buena fe y confianza legítima). Por su parte, el principio de desarrollo sostenible, que será también objeto de análisis, es de más reciente acuñación y, de hecho, se encuentra sujeto aún a una continua evolución en su delimitación conceptual. En todo caso, esta selección no excluye que otros principios jurídicos puedan tener incidencia en el ejercicio de las facultades urbanísticas.

\section{A) Principio de proporcionalidad}

El principio de proporcionalidad, entendido en una concepción amplia como necesidad de adecuación entre medio utilizado y fin perseguido, y como equilibrio entre intereses implicados, es uno de los principios generales de nuestro ordenamiento jurídico. Así lo reconoció tempranamente nuestro Tribunal Constitucional, en su Sentencia 62/1982, de 15 de octubre (RTC 1982/62), en la que afirma:

"De acuerdo con las ideas anteriores, para determinar si las medidas aplicadas eran necesarias para el fin perseguido, hemos de examinar si se han ajustado o si han infringido el principio de proporcionalidad. La Sala no ignora la dificultad de aplicar en un caso concreto un principio general del derecho que, dada su formulación como concepto jurídico indeterminado, permite un margen de apreciación."

Desarrollado históricamente en el Derecho Penal, la formulación más aceptada en el Derecho Europeo del principio de proporcionalidad se debe al esfuerzo dogmático de la doctrina alemana. Ésta definió el principio sobre la base de tres criterios o subprincipios escalonados cuya integración permite conformar su significado y alcance ${ }^{31}$.

${ }^{31}$ Un estudio más profundo de la doctrina alemana sobre el principio de proporcionalidad puede verse en BARNÉS VÁZQUEZ, Javier (1994) "Introducción al principio de proporcionalidad en el Derecho Comparado y Comunitario", Revista de Administración Pública 135 y LÓPEZ GONZÁLEZ José Ignacio (1988): "El principio general de proporcionalidad en derecho administrativo", $1^{a}$ edición, Instituto García Oviedo, Sevilla, págs. 40-46. Asimismo, vid. CARLÓN RUIZ, Matilde (2010) "El principio de proporcionalidad", en la obra colectiva, "Los principios jurídicos del Derecho Administrativo", $1^{\circ}$ ed., La Ley, Madrid, págs. 206-208. Igualmente, se aborda el estudio de la doctrina alemana sobre el principio de proporcionalidad, desde la perspectiva de técnica de control de la discrecionalidad del planeamiento urbanístico, en PONCE SOLÉ, Julio (1996): "Discrecionalidad urbanística y autonomía municipal", 1ª edición, Givitas, Madrid, págs. 194 y ss. y DESDENTADO DAROCA, Eva (1999) "Discrecionalidad Administrativa y Planeamiento Urbanístico", $2^{a}$ edición, Aranzadi, Navarra, págs. 162-170 y 241-252. 
El primero de esos subprincipios es el llamado de idoneidad. Este subprincipio alude a la aptitud de la medida de intervención pública a adoptar para la consecución del fin público perseguido. De esta forma, la aplicación de este primer criterio permite excluir, por desproporcionadas, todas aquellas medidas que resulten manifiestamente inútiles para la satisfacción del concreto interés público que se pretenda satisfacer.

El segundo es el de necesidad, que supone un paso más en la concreción de la medida de intervención pública proporcionada. La aplicación de este subprincipio comporta que la medida idónea para la consecución del fin público ha de ser, además, la menos restrictiva para la esfera de intereses particulares, es decir, que siendo varias las posibles medidas, y todas ellas igualmente eficaces para la consecución del fin, ha de escogerse la menos lesiva para la persona afectada. Desde la perspectiva del criterio de la necesidad, el principio de proporcionalidad se vincula con el denominado principio favor libertatis; principio que, fundado en el reconocimiento de la libertad y la dignidad de la persona, como valores materiales del ordenamiento jurídico, impone a los poderes públicos el deber de adoptar las soluciones menos restrictivas de los derechos de los particulares, en una clara función tuitiva de los intereses individuales ${ }^{32}$.

El último de los subprincipios es el de proporcionalidad en sentido estricto, que supone una ponderación entre el fin público que se pretende obtener con la medida y el perjuicio que la misma comporta para el particular, es decir, una valoración tendente a determinar si la consecución del interés público justifica el sacrificio del interés particular ${ }^{33}$.

La aplicación sucesiva de estos tres criterios permite determinar, al menos teóricamente, si la medida pública de intervención ha de ser o no considerada proporcional. No obstante, debe tenerse presente que estos principios refieren conceptos de una gran indeterminación respecto de los que el ordenamiento jurídico en pocas ocasiones proporcionará los elementos necesarios para su integración.

${ }^{32}$ A este respecto, para LÓPEZ GONZÁLEZ, el principio de favor libertatis, expresión del valor de la libertad y dignidad de la persona, se erige como exigencia constitucional del principio de proporcionalidad de la actividad administrativa. Los valores de libertad y dignidad, junto con el de justicia material, propugnados todos ellos por la Constitución, constituyen el fundamento del principio de proporcionalidad (LÓPEZ GONZÁLEZ, José Ignacio (1988): 78-81).

${ }^{33}$ Este tercer criterio coincide en su formulación con la doctrina del Consejo de Estado Francés del bilan-coût-avantages (costes-beneficios), cuyo empleo trata de determinar si la actuación administrativa comporta un coste financiero o social excesivamente elevado en relación con el fin que se pretende conseguir. 
Ello comporta que, frecuentemente, la determinación de si una medida es o no proporcional estará sujeta al criterio subjetivo del aplicador del Derecho ${ }^{34}$.

La introducción del principio de proporcionalidad en el Derecho administrativo se produjo a través del denominado Derecho de Policía. Particularmente, en el ordenamiento administrativo español, la primera formulación más o menos implícita del principio se produjo en el ámbito local, concretamente en el artículo 6 del Reglamento de Servicios de la Corporaciones Locales, aprobado por Decreto de 17 de junio de 1955. El tenor de dicho precepto es el siguiente:

"1. El contenido de los actos de intervención será congruente con los motivos y fines que los justifiquen.

\section{Si fueren varios los admisibles, se elegirá el menos restrictivo de la Libertad individual."}

Como puede apreciarse, en esta formulación, se encuentran presentes dos de los criterios que definen el principio de proporcionalidad según la doctrina alemana: el de la idoneidad y el de la necesidad. Dada la claridad de su redacción, el precepto, pese a su carácter reglamentario, ha ejercido una importante función informadora e interpretativa de la regulación y control de las actividades administrativas de intervención de las entidades locales ${ }^{35}$.

La Constitución no formalizó de forma expresa el principio de proporcionalidad. No obstante ello, el mismo puede ser deducido del espíritu y del tenor de algunos preceptos del texto constitucional, especialmente del artículo 106.1, según lo ha declarado el Tribunal Supremo ${ }^{36}$. De conformidad con dicho precepto, que se refiere al control jurisdiccional de la actividad de la Administración, dicha actividad queda sometida "a los fines que la justifican". Este artículo ha de ponerse en conexión con el artículo 103.1 de la Constitución, que dispone que " $L a$ Administración Pública sirve con objetividad a los intereses generales y actúa (...) con sometimiento pleno a la Ley y el Derecho".

\footnotetext{
${ }^{34}$ En este sentido, DESDENTADO DAROCA se refiere a la necesidad de que los tribunales hagan uso de esta técnica con suma prudencia, ante el riesgo de sustitución judicial de decisiones administrativas que distan de ser manifiestamente desproporcionadas (vid. DESDENTADO DAROCA, Eva (1999): 249 y ss.) En esta línea, vid. BARNÉS VÁZQUEZ, Javier (1998): "El Principio de proporcionalidad. Estudio Preliminar", Cuadernos de Derecho Público 5, fundamentalmente págs.43-49.

${ }^{35}$ LÓPEZ GONZÁLEZ, José Ignacio (1988): 20.

${ }^{36}$ Especialmente relevantes, a este respecto, son la STS de 16 de mayo de 1990 (RJ 1990/4167) y la de 18 de febrero de 1992 (RJ 1992/2904), cuyo fundamento jurídico $4^{\circ}$ se transcribe parcialmente:
} 
La lectura conjunta de ambos preceptos permite identificar los elementos del principio de proporcionalidad: de una parte, la actuación de la Administración ha de ajustarse siempre a los fines que la justifican, deber que implica, no ya la prohibición para la Administración de perseguir fines distintos (desviación de poder), sino la necesidad de que dicha actuación sea adecuada al fin que la respal$\mathrm{da}^{37}$. De otra parte, los fines que justifican la actuación de la Administración se identifican en todo caso con el interés público, a cuya satisfacción debe ir referida toda actuación pública.

A partir de la incorporación del principio en la norma superior de nuestro ordenamiento, se explica su inclusión, más o menos expresa, en una gran diversidad de normas, entre las que cabe considerar tanto aquellas que establecen el régimen estatutario de la Administración -Ley 7/1985, de 2 de abril, reguladora de las bases del régimen local ${ }^{38}$ y Ley 30/1992, de 26 de noviembre, de régimen jurídico de las Administraciones Públicas y Procedimiento Administrativo Común ${ }^{39}$ - como otras que inciden en el funcionamiento de los sectores económicos: la Ley 9/2014, de 9 de mayo, General de Telecomunicaciones; la Ley de Economía Sostenible; la Ley 20/2013, de 9 de diciembre, de garantía de la uni-

"Uno de estos principios, reiteradamente invocado por la jurisprudencia, es de proporcionalidad -SS. 6-12-1986 ( Rf 1986\8101), 7 febrero y 29 diciembre 1987 ( Rf 198712908 y Rf 198719860 ), 30 abril y 22 julio 1988 ( Rf 198813294 y Rf $1988 \backslash 6328$ ), o julio y 16 octubre 1989 ( Rf $1989 \backslash 5592$ y Rf $1989 \backslash 7368$ ), 18-4-1990 ( Rf 199013601 ), 4 abrily 3 diciembre 1991 ( Rf 199113286 y Rf 199119389 ), etc.- que deriva claramente del art. 106,1 de la Constitución que al dibujar el control jurisdiccional de la Administración alude al sometimiento de la actuación administrativa a los fines que la justifican: aunque en ocasiones este precepto se ha entendido como una alusión a la desviación de poder, su sentido es mucho más amplio y recoge la necesidad de una armonía entre los medios utilizados y la finalidad perseguida. En la misma línea, el principio de proporcionalidad tiene expresión en los arts. 84,2 de la Ley Reguladora de las Bases del Régimen Local 7/1985 y 6. ${ }^{\circ}$ del Reglamento de Servicios de las Corporaciones Locales."

${ }^{37}$ En este sentido, vid. LÓPEZ GONZÁLEZ, José Ignacio (1988): 86. Asimismo, vid. STS de 18 de febrero de 1992 (RJ 1992/2904), antes citada.

${ }^{38}$ Artículo 84.2

${ }^{39}$ Según el apartado primero del artículo 39 bis de esta disposición: "Las Administraciones Públicas que en el ejercicio de sus respectivas competencias establezcan medidas que limiten el ejercicio de derechos individuales o colectivos o exijan el cumplimiento de requisitos para el desarrollo de una actividad, deberán elegir la medida menos restrictiva, motivar su necesidad para la protección del interés público así como justificar su adecuación para lograr los fines que se persiguen, sin que en ningún caso se produzcan diferencias de trato discriminatorias." Otras referencias de la Ley de Procedimiento Administrativo al principio de proporcionalidad se encuentran, en relación con distintas formas de actividad administrativa, en sus artículos 4.1.b) -articulación de competencias entre Administraciones Territoriales- 53.2 -producción de actos administrativo - 96 - medios de ejecución forzosa de resoluciones administrativas- y 131 -ejercicio de la potestad sancionadora- ${ }^{-}$ 
dad de mercado, y el Texto Refundido de la Ley de Puertos del Estado y de la Marina Mercante, aprobado por Real Decreto Legislativo 2/2011, de 5 de septiembre, etc.

En el ámbito urbanístico, como se verá, el principio de proporcionalidad, además de cumplir una función esencial como límite de la potestad discrecional de planificación, constituye asimismo un parámetro de control importante en la aplicación de las medidas de reacción frente a actos de edificación y uso del suelo contrarios a la legalidad urbanística.

B) Principios de igualdad y de interdicción de la arbitrariedad

El de igualdad es un concepto nuclear de todo ordenamiento constitucional. $\mathrm{Es}$, desde luego, una de las máximas que ha de regir el funcionamiento de todo Estado civilizado y, por ello, se encuentra presente en las múltiples expresiones de su vida.

No es fácil ofrecer una noción de igualdad, habida cuenta que se trata de un concepto que ofrece matices diversos y que ha ido experimentando variaciones en su sentido y aplicación desde el constitucionalismo puramente liberal hasta la consagración del Estado social.

Como primera idea, ha de señalarse que la noción igualdad presenta una dimensión relacional, es decir, su concreción implica tener en cuenta a una pluralidad de personas y situaciones, de suerte que sin la existencia de un término de comparación no es posible determinar lo que es igual y lo que es desigual ${ }^{40}$.Y como segunda idea, hay que tener presente que esta relación de comparación consustancial al concepto de igualdad se establece entre personas y situaciones que presentan semejanzas, pero también diferencias. En este sentido, igualdad no equivale a identidad.

Partiendo de estas premisas, es posible ofrecer una primera aproximación a la noción de igualdad. Se trata de un criterio filosófico-jurídico que implica que las personas deben ser tratadas iguales, pese a que entre ellas no se dé una absoluta identidad en sus caracteres -igualdad como equiparación y homogeneización- Y

${ }^{40}$ Se ha afirmado, en este sentido, que mientras una proposición como «X es libre» es una proposición dotada de sentido, una proposición del tipo «X es iguab» carece de sentido, y, para adquirirlo, hay que establecer una relación de comparación en la que se precise respecto a quién y en qué es igual (MARTÍNEZ TAPIA, Ramón (2000): "Igualdad y Razonabilidad en la justicia constitucional española", Universidad de Almería. Servicio de Publicaciones, Almería, pág. 15). 
ello, porque, aun existiendo diferencias, las mismas no son consideradas relevantes como para fundamentar un trato desigual. Ahora bien, puede ocurrir que esas diferencias y situaciones sí sean consideradas relevantes, en cuyo caso podrán justificar un trato desigual. Se alude entonces a la igualdad como diferenciación.

A partir de este concepto se puede trazar una primera categorización del principio de igualdad: la igualdad formal y la igualdad material o efectiva.

La igualdad formal comporta que todos los sujetos que se hallan en la misma situación merecen recibir un mismo trato, en tanto que los que se encuentran en distinta situación deben ser tratados de forma diferente -aunque igual en cada una de ellas ${ }^{-41}$ La igualdad formal se consagra en el artículo $14 \mathrm{CE}$, de cuyo tenor se deduce un doble mandato.

En primer lugar, declara el precepto que "los españoles son iguales ante la Ley", es decir, impone el tratamiento igual a los iguales -igualdad como equiparación-. El reverso de esta imposición sería la de tratar de forma desigual a los que son desiguales - lo que antes se denominó igualdad como diferenciación- mas lo cierto es que nuestro Tribunal Constitucional ha considerado que el artículo 14 no incorpora dicha última prescripción ${ }^{42}$. El segundo mandato contenido en el artículo $14 \mathrm{CE}$ es el de no discriminación, expresado a través del inciso "sin que pueda prevalecer discriminación alguna por razón de nacimiento, raza, sexo, religión, opinión o cualquier otra condición o circunstancia personal o social."

En el ámbito de la igualdad formal suele distinguirse, a su vez, entre igualdad "en la ley" e igualdad "en aplicación de la ley". La primera implica que las entidades que ejercen poderes normativos -las Cortes y la Administración- no van a poder configurar los supuestos de hecho de la norma de modo tal que se dé trato distinto a personas que, desde todos los puntos de vista legítimamente adoptables, se encuentran en la misma situación. La igualdad "en aplicación de la Ley" supone que los aplicadores del Derecho -la Administración y los órga-

${ }^{41}$ SANTAMARÍA IBEAS, José Javier (1997): "Los valores superiores en la jurisprudencia del Tribunal Constitucional", Dykinson, pág. 284.

${ }^{42}$ En este sentido, la STC 86/1985, de 10 de julio (RTC 1985/86), sostiene que "la discriminación por indiferenciación no puede situarse en el ámbito del artículo 14 de la Constitución (...) lo que el artículo 14 impide es la distinción infundada o discriminación (...)" pero no contiene "un derecho fundamental a la singularización normativa". En este mismo sentido, y de forma taxativa, la STC 16/1994, de 20 de enero (RTG 1994/16), señala que "la igualdad del artículo 14 impide tratar desigualmente a los iguales, pero no excluye la posibilidad de tratar igualmente a los desiguales." 
nos jurisdiccionales- deben aplicar las normas de modo igual a todos aquellos que se encuentran en la misma situación, o lo que es lo mismo, no pueden modificar arbitrariamente el sentido de sus decisiones en casos sustancialmente iguales, de manera que cuando el órgano en cuestión considere que debe apartarse de sus procedentes tiene que ofrecer para ello una fundamentación suficiente y razonable ${ }^{43}$.

En cualquier caso, la igualdad formal o igualdad ante la ley no comporta, como señala la STC 49/1982, de 14 de julio (RTC 1982/49) una igualdad material o igualdad económica real y efectiva. El principio de igualdad material se consagra en el artículo 9.2 CE, que impone a los poderes públicos "promover las condiciones para que la libertad y la igualdad del individuo y de los grupos en que se integra sean reales y efectivas; remover los obstáculos que impidan o dificulten su plenitud y facilitar la participación de todos los ciudadanos en la vida política, económica, cultural y social.". Sobre este precepto, ha señalado el Tribunal Constitucional que "puede actuar como un principio matizador de la igualdad formal consagrada en el art. 14 de la Constitución, permitiendo regulaciones cuya desigualdad formal se justifica en la promoción de la igualdad material $(\ldots)^{344}$

Así pues, conforme a la igualdad material, considerada como una exigencia del Estado social, el ordenamiento debe distinguir entre la situación teórica y la situación práctica en que se encuentran sus destinatarios. De esta manera, es admisible y aun exigible que aquellos sujetos que, pese a encontrarse jurídicamente en la misma situación que otros, se hallen materialmente en situación de desi-

43 SSTC 49/1982, de 4 de julio (RTC 1982/49) y 144/1988, de 12 de julio (RTC 1988/144).

${ }^{44}$ STC 98/1985, de 29 de julio (RTG 1985/98). Ciertamente, el artículo 9.2 CE es el precepto que con mayor sustantividad constitucionaliza el concepto de igualdad material, pero ello no significa que lo haga de forma exclusiva y que, frente al mismo, el artículo 14 se limite a consagrar una concepción meramente formal de la igualdad. En este sentido, se ha sostenido que "la superación de los presupuestos estrictamente liberales que en su origen nutrieron la idea de igualdad, hace también hoy prácticamente imposible que el art. 14 siga significando sólo y exclusivamente protección de la igualdad jurídico-formal (...) pues la inevitable presencia de las premisas materiales y sociales que comporta todo juicio de igualdad, y una interpretación sistemática del art. 14, llevan a que este artículo cubra, en no pequeña parte, el contenido de la igualdad material. El artículo 9.2 debería, entonces, quedar reservado a aquellos supuestos de desigualdad material cuya corrección, además, comporte la necesidad de provocar un avance social intenso, sirviendo, asimismo, de soporte a determinadas recomendaciones al legislador dirigidas a que remueva los obstáculos sociales que impidan la igualdad”. A este respecto, y en línea con lo afirmado en la sentencia referida, Pérez Luño sostiene que nuestra jurisprudencia constitucional no concibe las dos vertientes del principio de igualdad como compartimentos estancos, sino que tiende a conjugar y orientar la interpretación del art. 14 en función del artículo 9.2 y 1.1 (vid. MARTíNEZ TAPIA, Ramón (2000): 59 y 60, así como las obras citadas por el autor). 
gualdad, sean tratados de forma diferente hasta tanto puedan lograr ejercer de forma efectiva la igualdad ${ }^{45}$. La consecución de ese objetivo justifica ética y constitucionalmente la adopción de acciones y políticas de diferenciación para la igualdad, incluida la denominada discriminación positiva ${ }^{46}$.

El principio de igualdad, proclamado como uno de los principios esenciales del ordenamiento constitucional, ejerce un papel protagonista en varios ámbitos del Derecho Administrativo. Así, por ejemplo, en el de la Función Pública ${ }^{47}$, en la Contratación Pública ${ }^{48}$, en el régimen de las Subvenciones ${ }^{49}$ y en el sistema tributario $^{50}$ También domina, como veremos más adelante, el ordenamiento urbanístico.

Por último, el concepto de igualdad presenta una indudable conexión con el de interdicción de la arbitrariedad, que se consagra en el artículo 9.3 de la CE.

En un sentido amplio, se ha definido la arbitrariedad como toda actuación

${ }^{45}$ SANTAMARÍA IBEAS, José Javier (1997): 284.

${ }^{46}$ En esta línea, ha señalado el Tribunal Constitucional que "la incidencia del mandato contenido en el art. 9.2 sobre el que, en cuanto se dirige a los poderes públicos, encierra el art. 14 supone una modulación de este último, en el sentido, por ejemplo, de que no podrá reputarse de discriminatoria y constitucionalmente prohibida -antes al contrario- la acción de favorecimiento, siquiera temporal, que aquellos poderes emprendan en beneficio de determinados colectivos, históricamente preteridos y marginados, a fin de que, mediante un trato especial más favorable, vean suavizada o compensada su situación de desigualdad sustancial" (STC 216/1991, de 14 de noviembre, RTC 1991/216). En el mismo sentido se pronuncia, entre otras muchas, la STC 3/1993, de 14 de enero (RTC 1993/3).

${ }^{47}$ En este sentido, ya la propia CE reconoce en su artículo 23.2, como derecho fundamental, el de acceder en condiciones de igualdad a las funciones y cargos públicos. El contenido de ese derecho, concreción del más genérico del artículo 14, es desarrollado por la Ley 7/2007, de 12 de abril, por la que se aprueba el Estatuto del Empleado Público, cuyo artículo 1.3 incluye entre los fundamentos de la Administración en este ámbito la "Igualdad, mérito y capacidad en el acceso y en la promoción profesional" (apartado b.) y la "Igualdad de trato entre mujeres y hombres" (apartado d.)

48 Así, el artículo 1 del Texto Refundido de la Ley de Contratos del Sector Público, aprobado por Real Decreto Legislativo 3/2011, de 14 de noviembre, afirma que el objeto de la ley es "regular la contratación del sector público, a fin de garantizar que la misma se ajusta a los principios de libertad de acceso a las licitaciones, publicidad y transparencia de los procedimientos, y no discriminación e igualdad de trato entre los candidatos". Y abundando en esta idea, el artículo 139 señala que "los órganos de contratación darán a los licitadores y candidatos un tratamiento igualitario y no discriminatorio y ajustarán su actuación al principio de transparencia".

${ }^{49}$ A este respecto, la gestión de subvenciones públicas ha de realizarse de acuerdo con el principio de igualdad y no discriminación, de conformidad con el artículo 8.3.a) de la Ley 38/2003, de 17 de noviembre, General de Subvenciones.

${ }^{50} \mathrm{En}$ el ámbito tributario rige el principio de igualdad junto con el de progresividad como reglas básicas del sistema (artículo 31.1 de la $\mathrm{CE}$ ) 
contraria a la legalidad, definición que resulta extremadamente genérica y que no permite identificar un principio de interdicción de la arbitrariedad con sus propios perfiles. Cabe, no obstante, una noción más precisa de la arbitrariedad como actuación carente de todo tipo fundamento - no sólo jurídico, sino también lógico- Desde esta perspectiva, lo que identificaría al acto arbitrario no es su disconformidad con el Derecho en general, sino su contradicción con las más elementales reglas de la racionalidad humana ${ }^{51}$.

La arbitrariedad se relaciona con la discriminación, pero el acto arbitrario no es necesariamente discriminatorio. Así, no hay más que comprobar que el acto arbitrario lo es en sí mismo, sin necesidad de ponerlo en relación con otra actuación del poder público, siendo así que, por el contrario, la atribución a una actuación pública - normativa o aplicativa del Derecho- de la condición de discriminatoria requiere, como se ha señalado antes, la previa comparación de ella con otra actuación - exigencia de un término de comparación- .

Ahora bien, dicho lo anterior, no cabe duda de que el concepto de interdicción de la arbitrariedad tiene una evidente vinculación con el de la igualdad. A este respecto, la interdicción de la arbitrariedad vendría a constituir, respecto del principio de igualdad, un instrumento tendente a garantizar que la actuación pública no sea discriminatoria, mediante la incorporación de la exigencia de racionalidad en las motivaciones que sirven de base al trato diferenciado que la Administración propina en ocasiones a los ciudadanos. En esta línea, el Tribunal Constitucional ha venido sosteniendo que los poderes públicos incurren en arbitrariedad cuando en su actuación provocan discriminaciones o desigualdades carentes de justificación objetiva y razonable. ${ }^{52}$

Como se verá más adelante, el principio de interdicción de la arbitrariedad también tiene incidencia en el ejercicio de las potestades urbanísticas.

C) Principios de seguridad jurídica, buena fe y confianza legítima

El principio de seguridad jurídica es otro de los principios fundamentales de nuestro ordenamiento jurídico. Incluido entre los principios recogidos en el

51 Vid. en este sentido, DESDENTADO DAROCA, Eva (2010): "El principio de interdicción de la arbitrariedad" en la obra colectiva "Los principios jurídicos del Derecho Administrativo", $1^{\circ}$ ed., La Ley, Madrid, pág. 182 y PONCE SOLÉ, Julio (1996): 214.

52 Así, entre otras, la STC 67/1982, de 15 de noviembre (RTC 1982/67) o la citada STC 144/1988, de 12 de julio (RTC 1988/144). A este respecto, vid. LEGUINA VILLA, Jesús (1987): 32. 
artículo 9.3 de la $\mathrm{CE}$, se ha afirmado que el principio de seguridad jurídica viene a ser el compendio, la síntesis o el resultado de los demás principios constitucionales, en cuanto "que es suma de certeza y legalidad, jerarquía y publicidad normativa, irretroactividad de lo no favorable e interdicción de la arbitrariedad (...) equilibrada de tal suerte que permita promover, en el orden jurídico, la justicia y la igualdad en libertad ${ }^{53}$.

La idea de seguridad jurídica, que sugiere certeza o certidumbre del derecho, responde a la necesidad del ciudadano de conocer su situación jurídica y de saber a qué atenerse en cada momento, esto es, de conocer de antemano las consecuencias jurídicas de sus actos ${ }^{54}$. Desde esta perspectiva, el principio de seguridad jurídica constituye el elemento que dota al ordenamiento jurídico de estabilidad, certeza y previsibilidad, facilitando la convivencia armónica y congruente entre los miembros de la sociedad ${ }^{55}$.

Esta necesidad de certeza y previsibilidad a que responde el principio de seguridad jurídica está especialmente presente en ordenamientos como el español, en los que existe una pluralidad de centros de producción normativa. Y es más acusada aún en el ámbito del Derecho Administrativo, caracterizado, como ya se ha notado en este trabajo, por el fenómeno de la legislación motorizada, que alude a una producción normativa contingente y ocasional, imposible de ser seguida por el jurista ${ }^{56}$. Así pues, el principio de seguridad jurídica se erige en elemento imprescindible para la comprensión y funcionamiento del ordenamiento jurídico y, especialmente, del jurídico-administrativo.

53 STC 27/1981, de 20 de julio (RTC 1981/27).

54 Según PÉREZ LUÑO, la formación del concepto de seguridad jurídica "no ha sido la consecuencia de una elaboración lógica sino el resultado de las conquistas políticas de la sociedad. La seguridad constituye un deseo arraigado en la vida anímica del hombre, que siente terror ante la inseguridad de su existencia, ante la imprevisibilidad y la incertidumbre a que está sometido. La exigencia de seguridad de orientación es, por eso, una de las necesidades humanas básicas que el Derecho trata de satisfacer a través de la dimensión jurídica de la seguridad" (PÉREZ LUÑO, Antonio Enrique (2003): "La seguridad jurídica" en la obra colectiva "Teoría del Derecho y Filosofía del Derecho", $1^{a}$ edición (digital), Iustel, Madrid, pág 1).

55 RODRÍGUEZ-ARANA MUÑOZ, Jaime (2008): 55.

${ }^{56}$ En este sentido, CASTILLO BLANCO afirma que "la proliferación de las normas jurídicas, un verdadero huracán normativo, a la que asistimos en la actualidad, producto de múltiples razones como la creación de nuevos centros de poder legislativo como son la Comunidad Económica Europea y las Comunidades Autónomas, la ruptura de la estricta separación de poderes que ha llevado a que el poder ejecutivo se convierta también en una importante fuente de producción legislativa, la irrupción del Estado en múltiples sectores de la sociedad regulando su intervención, el frenético cambio normativo, el desarrollo de la sociedad de la información, la celeridad y la agilidad en la contratación y, en general, la vivacidad y la aceleración del tráfico jurídico, han determinado finalmente la aspiración le- 
El principio de seguridad jurídica se expresa, según LEGUINA, en una triple dimensión: como conocimiento y certeza del Derecho positivo; como confianza de los ciudadanos en las instituciones públicas y en el orden jurídico en general, en cuanto garantes de la paz social y, finalmente, como previsibilidad de las consecuencias jurídicas derivadas de las propias acciones o de las conductas de ter$\operatorname{ceros}^{57}$. Esta consideración resulta coherente con la conceptualización del principio que realiza el Tribunal Constitucional, sobre la base de dos elementos: el objetivo, que alude a la certeza de la norma, y el subjetivo, que se refiere a la previsibilidad de los efectos de su aplicación por los poderes públicos ${ }^{58}$. Así pues, la seguridad jurídica, por una parte, garantiza el conocimiento de las normas y, por otro, confiere a los ciudadanos una pauta de comportamiento sobre la base de la estabilidad de los procesos de aplicación de las mismas.

Por lo demás, en cuanto a su alcance, el principio de seguridad jurídica opera, como puede deducirse de lo anterior, tanto en el ámbito de la producción de las normas como en el de su aplicación, ya sea por la Administración, ya por los órganos judiciales ${ }^{59}$. En este sentido, son manifestaciones de lo primero, entre otras, la reserva de ley, el sistema de vigencia y derogaciones normativas, la irretroactividad, el respeto a los derechos adquiridos y la publicidad de las normas. Por su parte, en el ámbito de la aplicación normativa son exigencias del principio de seguridad jurídica la inderogabilidad singular de los reglamentos y el silencio administrativo. Y concretamente en lo que hace a la aplicación judicial del Derecho, el principio de iura novit curia, la necesidad de motivación de las sentencias y la condición de firmeza de las resoluciones judiciales.

gítima, por otra parte, de armonizar las necesidades de cambio con la seguridad jurídica" (CASTILLO BLANCO, Federico A. (2002): "El principio de seguridad jurídica: especial referencia a la certeza en la creación del derecho", Documentación Administrativa 263-264, págs. 22-23).

${ }^{57}$ LEGUINA VILLA, J. (1987). En similar sentido, CASTILLO BLANCO afirma que la seguridad jurídica "supone la necesidad de que el individuo obtenga del Derecho certeza en sus actuaciones frente a actuaciones de otros individuos, que le permita conocer las consecuencias de las mismas y simultáneamente confianza en que el Derecho protegerá las mismas actuaciones conformadas de acuerdo a la legalidad." (CASTILLO BLANCO, Federico A. (2002): 33).

${ }^{58}$ SSTC 35/1991, de 14 de febrero (RTC 35/1991), 130/1999, de 1 de julio (RTC 1999/130), y 273/2000, de 15 de noviembre (RTC 2000/273).

${ }^{59}$ Sobre los ámbitos de actuación del principio de seguridad jurídica, vid. BERMEJO VERA, José (2010): "El Principio de seguridad jurídica" en la obra colectiva "Los principios jurídicos del Derecho Administrativo", $1^{\circ}$ ed., La Ley, Madrid, págs. 84 y ss.; PÉREZ LUÑO, Antonio Enrique (2003) y HIERRO SÁNCHEZ-PESCADOR, Liborio Luis (1989): "Seguridad jurídica y actuación administrativa”, Documentación Administrativa n ${ }^{\circ}$ 218-219. 
Los principios de buena fe y de confianza legítima, por su parte, constituyen dos proyecciones o derivaciones de la seguridad jurídica ${ }^{60}$. Ambos se hallan incorporados en el artículo 3.1 de la LRJPAC, cuyo último inciso señala que las Administraciones Públicas "deberán respetar en su actuación los principios de buena fe y de confianza legítima".

Aunque formulados como principios independientes, lo cierto es que no es fácil establecer una clara diferenciación entre ambos, pues los dos protegen el mismo valor: la coherencia del comportamiento de una de las partes de la relación jurídica con las legítimas expectativas de la otra sobre dicho comportamiento. Ello explica que la jurisprudencia aún se refiera a ambos principios de manera indiscriminada ${ }^{61}$.

Así pues, la virtualidad de los principios de buena fe y confianza legítima es que imponen a la Administración -y también al particular- un deber de coherencia con un comportamiento precedente. Es decir, la observación de estos principios determina la obligación de respetar los actos adoptados o situaciones creadas a partir de una conducta previa de una de las partes que, por estar revestida de legalidad, generó unas legítimas expectativas en la otra, expectativas que, justamente por consideración al valor de la confianza, no pueden ser posteriormente defraudadas.

${ }^{60}$ Así lo señala expresamente la Exposición de Motivos de la Ley 4/1999, de 13 de enero, de modificación de la Ley de Régimen Jurídico de las Administraciones Públicas y Procedimiento Administrativo Común: "en primer lugar, en el Título preliminar se introducen dos principios de actuación de las $A d-$ ministraciones públicas, derivados del de seguridad jurídica. Por una parte, el principio de buena fe, aplicado por la jurisprudencia contencioso-administrativa incluso antes de su recepción por el Título Preliminar del Código Civil. Por otra, el principio, bien conocido en el derecho procedimental administrativo europeo y también recogido por la jurisprudencia contencioso-administrativa, de la confianza legítima de los ciudadanos en que la actuación de las Administraciones públicas no puede ser alterada arbitrariamente." Asimismo, vid. SSTS de 4 de junio de 2001 (RJ 2002/448) y 21 de diciembre de ese mismo año (RJ 2002/4915).

${ }^{61}$ Con todo, es posible encontrar, según algunos autores, ciertas normas diferenciadoras de ambos principios. Tres son las apuntadas, que expresamos de forma sintética: que el principio de buena fe incorpora un componente ético que no está presente, o al menos no en la misma medida, en el de confianza legítima; que el principio de buena fe requiere para operar, al menos en mayor medida que el principio de confianza legítima, que las partes de la relación jurídica se hallen en un plano de igualdad; por último, que la buena fe tiene un campo de acción más restringido que el de la confianza legítima. A este respecto, vid. CASTILLO BLANCO, Federico A. (1998): "La protección de la confianza en el Derecho Administrativo", 1ª edición, Marcial Pons, Madrid, págs. 253 y ss; GARCIIA LUENGO, Javier (2002): "El principio de protección de la confianza legítima en el Derecho Administrativo”, $1^{a}$ edición, Civitas, Madrid, págs. 121 y ss.; y PAREJO ALFONSO, Luciano (1998): Prólogo a la obra de Castillo Blanco "La protección de la confianza en el Derecho Administrativo", 1ª edición, Marcial Pons, Madrid, pág. 18. 
Particular trascendencia en el ámbito jurídico administrativo tienen estos principios en su papel de límite al ejercicio de la potestad de revisión de actuaciones administrativas. Así se pone de manifiesto en el artículo 106 de la Ley de Procedimiento Administrativo, que afirma que "las facultades de revisión no podrán ser ejercitadas cuando por prescripción de acciones, por el tiempo transcurrido o por otras circunstancias, su ejercicio resulte contrario a la equidad, a la buena fe, al derecho de los particulares o a las leyes. ${ }^{\prime 22}$ Por lo demás, en el ámbito urbanístico, como se verá más adelante, la observancia de los principios de buena fe y confianza legítima, y en general del de seguridad jurídica, comporta una modulación de las facultades administrativas de reacción frente a la comisión de actos urbanísticos ilegales.

D) Principio de desarrollo urbano sostenible

La expresión "desarrollo sostenible" se ha convertido en los últimos años en un tópico. Una fórmula meramente retórica y políticamente correcta que es empleada frecuentemente por los administradores públicos, sin que se sepa exactamente cuál es su significado.

Lo cierto es que el de "desarrollo sostenible" es un concepto jurídico muy difícil de determinar, en la medida en que se trata de una noción que se encuentra en constante evolución, incorporando continuamente nuevas vertientes y aplicaciones que hacen de este principio una amalgama de ideas sumamente compleja.

La expresión "desarrollo sostenible" fue introducida en el informe denominado "Nuestro Futuro Común", elaborado en 1987 por la Comisión mundial del medio ambiente y de desarrollo. Más conocido como Informe Brundtland, este documento contiene la definición primigenia del concepto de desarrollo sostenible: "el desarrollo que satisface las necesidades de la generación presente sin comprometer la capacidad de las generaciones futuras". Esta primera formulación, que presenta un contenido esencialmente ambiental, fue evolucionando a través de diversos documentos (la Declaración de Naciones Unidas sobre el medio ambiente y el desarrollo de Río de 1992 y los compromisos de las Cumbres de Copenhague de 1995 y de Johannesburgo de 2002) hacia concepciones más complejas, que cristalizarían en un principio de desarrollo sostenible basado en un triple pilar: am-

${ }^{62}$ Aunque el tenor literal del precepto alude "a la buena fe", se ha querido ver más en este límite a las potestades de revisión una manifestación del principio de confianza legítima (GARCíA LUENGO, Javier (2002): 243 y ss., especialmente pág. 107 y CASTILLO BLANCO, Federico A. (1998): 276 y ss., especialmente, pág. 281). 
biental, económico y social. Se trata, en definitiva, de posibilitar un desarrollo "socialmente deseable, económicamente viable y ecológicamente prudente" 63

La noción de desarrollo sostenible es considerada actualmente un elemento importante en las políticas de la Unión Europea y, en este sentido, este concepto se halla incorporado tanto al Tratado de la Unión Europea ${ }^{64}$, como al Tratado de Funcionamiento de la Unión ${ }^{65}$ (versiones consolidadas según el Tratado de Lisboa de 2007). Asimismo, la idea de desarrollo sostenible tiene presencia en los programas de la Unión sobre medio ambiente, sobre todo a partir del quinto programa comunitario de política y actuación en materia de medio ambiente, que, bajo el título "Hacia un Desarrollo Sostenible", atribuye a este concepto la condición de eje vertebrador de la política ambiental de la Unión.

Ha de subrayarse que la doctrina ha aceptado mayoritariamente la naturaleza jurídica del principio de desarrollo sostenible ${ }^{66}$. Se trata, en este sentido, de un verdadero principio del derecho que, como tal, cumple las funciones propias de estos. A este respecto, si bien la Constitución no refiere expresamente este principio, la doctrina ha reconocido en el artículo 45.2 de dicho texto - "Los poderes públicos velarán por la utilización racional de todos los recursos naturales con el fin de proteger y mejorar la calidad de vida y defender y restaurar el medio ambiente, apoyándose en la indispensable solidaridad colectiva"- en conexión con el artículo 40 -promoción del progreso social y económico- los elementos esenciales del mismo, de manera que es posible afirmar el reconocimiento constitucional del desarrollo sostenible como principio jurídico ${ }^{67}$.

63 Vid. STS de 20 de diciembre de 2006 (RJ 2006/9853).

${ }^{64}$ El Tratado de Lisboa de 2007 contempla el desarrollo sostenible entre los fines de la Unión (artículo 3.3) y como uno de los ámbitos de cooperación en el ámbito de las relaciones exteriores (artículos 3.5 y 21.2).

${ }^{65} \mathrm{El}$ derecho sostenible se reconoce, en relación con la protección del medio ambiente, como uno de los objetivos de las políticas y acciones de la Unión.

${ }^{66}$ En este sentido, vid, entre otros, MENÉNDEZ REXACH, Ángel (2003): "Urbanismo sostenible, clasificación del suelo y criterios indemnizatorios: estado de la cuestión y algunas propuestas", Revista de Derecho Urbanístico y Medio Ambiente 200, pág. 136; RAMALLO LÓPEZ, Fátima (2011): "El principio de desarrollo urbano sostenible. Un nuevo paradigma en la planificación urbanística", Revista Española de Derecho Administrativo 150, págs. 393 y ss.; PIÑAR MAÑAS, José Luis (2003): "El desarrollo sostenible como principio jurídico" en la obra colectiva "Estudios de Derecho Público Económico", 1ª ed., Civitas, Madrid, pág. 190 y ss.; ALENZA GARCíA, José Francisco (2010): "Desarrollo Sostenible" en la obra colectiva "Los principios jurídicos del Derecho Administrativo", $1^{\circ}$ ed., La Ley, Madrid, págs. 1401 y ss.

${ }^{67}$ En este sentido se ha expresado, entre otros, ALENZA GARCÍA. Para el autor "los elementos que componen este mandato constitucional -uso prudente y proporcionado de los recursos naturales, la referencia a la 
Sea como fuere, el concepto de desarrollo sostenible basado en los tres pilares: ambiental, económico y social, está presente hoy, por su carácter transversal, en todas las políticas públicas, y ha encontrado campo abonado para su aplicación en la planificación de la ciudad, configurándose a partir de esta conexión la idea de desarrollo urbano sostenible.

Entre los instrumentos que, en el plano internacional, han contribuido a la configuración de este último concepto cabe destacar la llamada Agenda 21, elaborada en el marco de la Cumbre de las Naciones Unidas de Río de 1992 y la carta Aalborg de 1994. En el ámbito comunitario, son muchos los documentos que han coadyuvado a perfilar el concepto de desarrollo urbano sostenible: el Libro Verde de 1990 sobre el medio ambiente urbano; el informe "Ciudades Europeas Sostenibles" (1996); las Comunicaciones elaboradas por la Comisión de la Unión Europea en los años 1997, "Hacia una política urbana de la Unión Europea", y 1998, "Marco de actuación para el desarrollo urbano sostenible de la Unión Europea"; la Estrategia Territorial Europea (1999); las comunicaciones "Hacia una estrategia temática sobre medio ambiente urbano" (2004) y "Una estrategia temática para el medio ambiente urbano" (2006); la Carta de Leipzig sobre la Ciudad Europea Sostenible (2007) y, por último, el informe de la Comisión "Ciudades del mañana: retos, visiones y caminos a seguir" (2011).

Toda la sucesión de documentos a que se acaba de hacer referencia han terminado por perfilar el contenido del principio de desarrollo urbano sostenible que, en gran medida, se corresponde con el de un modelo de ciudad sostenible que puede identificarse con el de ciudad compacta.

Se trata, de conformidad con las orientaciones contenidas en los instrumentos antes referidos, de un modelo de ciudad de alta densidad, policéntrica, y en la que se da primacía a la rehabilitación y renovación de la ciudad existente frente a nuevos crecimientos. Este modelo se opone al de ciudad difusa o de urbanización dispersa, extendido en Europa - y muy significativamente en España- y que ha demostrado ser altamente insostenible desde el punto de vista económico, social y ambiental.

Dicho esto, nuestro ordenamiento jurídico ha incorporado buena parte de los postulados que derivan del concepto de desarrollo urbano sostenible. Así, el

calidad de vida y no un desarrollo cuantitativo, la indispensable solidaridad colectiva, que puede proyectarse también sobre las futuras generaciones - se pueden enmarcar perfectamente en el principio del desarrollo sostenible, tal y como han entendido doctrina y jurisprudencia” (ALENZA GARCÍA, José Francisco (2010): 1392-1393). 
artículo 2 del Texto Refundido de la Ley del Suelo, aprobado por Real Decreto Legislativo 2/2008, de 20 de junio, lo eleva a la categoría de principio rector de las políticas sobre suelo, al afirmar que: "las políticas públicas relativas a la regulación, ordenación, ocupación, transformación y uso del suelo tienen como fin común la utilización de este recurso conforme al interés general y según el principio de desarrollo sostenible, sin perjuicio de los fines especificos que les atribuyan las Leyes." $\mathrm{El}$ precepto, por lo demás, incorpora de manera explícita algunos de los elementos que caracterizan al modelo de ciudad sostenible propuesto por la Unión Europea. Particularmente, propugna:

- el uso racional de los recursos naturales que armonice los requerimientos de la economía, el empleo, la cohesión social, la igualdad de trato y de oportunidades entre mujeres y hombres, la salud y la seguridad de las personas y la protección del medio ambiente, y

- la consecución de un medio urbano suficientemente dotado en el que se ocupe el suelo de manera eficiente, y en el que se combinen los usos de forma funcional, garantizando, en particular, la movilidad en coste y tiempo razonable, sobre la base de un adecuado equilibrio entre todos los medios de transporte; la accesibilidad universal; el uso eficiente de los recursos y de la energía, preferentemente de generación propia, así como la introducción de energías renovables; y la prevención y la minimización de los impactos negativos de los residuos urbanos y de la contaminación acústica.

El contenido de ese precepto se ve completado por lo dispuesto en el artículo 3 de la más reciente Ley 8/2013, de 26 de junio, de Rehabilitación, Regeneración y Renovación Urbanas, que establece los fines de las políticas públicas para un medio urbano más sostenible, eficiente y competitivo. Así, este último artículo profundiza en el modelo de ciudad sostenible, abundando en algunos de sus rasgos característicos: la mejora de la calidad y funcionalidad de las dotaciones, servicios y las infraestructuras; la localización de actividades económicas generadoras de empleo estable; la integración en el tejido urbano de usos compatibles con la función residencial para contribuir al equilibrio de las ciudades y de los núcleos residenciales, favoreciendo la diversidad de usos; fomento de la rehabilitación y puesta en valor del patrimonio urbanizado y edificado con valor histórico o cultural, y promoción del uso de energías renovables.

Todas estas premisas, elevadas, como se acaba de señalar, a la categoría de principio jurídico tiene una indudable incidencia en el ejercicio de las potestades urbanísticas. 


\section{Incidencia de estos principios en el ejercicio de las potestades urbanísticas}

Una vez que se han analizado los principios jurídicos que, nuestro parecer, afectan en mayor medida al ejercicio de la función urbanística. A continuación se examinará de forma concreta la incidencia de los mismos en el desarrollo de las actividades que integran tal función: planeamiento, gestión y disciplina urbanística.

\section{A) Planeamiento y gestión urbanística}

La potestad de planificación urbanística, entendida como la actuación pública consistente en definir el modelo de ciudad, identificando los objetivos a cumplir y articulando los medios precisos para su consecución, constituye uno de los ámbitos en los que la Administración dispone de mayor discrecionalidad ${ }^{68}$.

En efecto, como ha señalado la doctrina, la discrecionalidad del planeamiento urbanístico es una discrecionalidad de normación especialmente intensa, respecto de la que la legislación, aunque le impone ciertos límites - por ejemplo, los estándares urbanísticos- no establece una regulación detallada, sino que esencialmente determina unos criterios o principios básicos, dejando al planificador un amplio margen de actuación ${ }^{69}$. Si la discrecionalidad se caracteriza por la atribución a la Administración de la posibilidad de optar entre varias soluciones posibles - y jurídicamente correctas todas ellas- en el caso del planeamiento urbanístico, es claro, esa discrecionalidad es amplísima, habida cuenta de la casi infinita variedad de modelos de configuración de la ciudad de los que parte, a priori, el planificador. A este respecto, se ha afirmado que el que la elección del modelo de ciudad por el que opte el planificador se realice con arreglo a criterios extrajurídicos -sociológicos, económicos, arquitectónicos, ecológicos, históricos, artísticos, etc.- evidencia la clara discrecionalidad del planeamiento ${ }^{70}$.

${ }^{68}$ Así lo ha reconocido la jurisprudencia de forma reiterada. En este sentido suelen citarse las SSTS de 1 de diciembre de 1986 (RJ 1987/415); de 13 de febrero de 1992 (RJ 1992/2828); de 13 de julio de 1993 (RJ 1993/5576); de 1 de diciembre de 1998 (RJ 1998/9708); y de 23 de abril de 1998 (RJ 1998/3102).

${ }^{69}$ VERA JURADO, Diego e ILDEFONSO HUERTAS, Rosa (2003): "La ordenación urbanística", en la obra colectiva "Derecho Urbanístico de Andalucía", 1ª edición, Tirant Lo Blanch, Valencia, págs. 55-58.

${ }^{70}$ DELGADO BARRIO, Javier (1993): "El control de la discrecionalidad del planeamiento urbanístico", 1ª edición, Cuadernos Civitas, Madrid, pág. 20. 
Este importante margen de maniobrabilidad requiere arbitrar medidas tendentes a dirigir la actividad de planeamiento urbanístico, a limitar el enorme abanico inicial de opciones, y en esta función cumplen un papel fundamental los principios generales del derecho que, junto al denominado control de los hechos determinantes, integra el grupo de técnicas de control jurisdiccional de la discrecionalidad del planeamiento urbanístico. Además de estas técnicas, constituyen límites a la discrecionalidad del planificador el carácter reglado de las licencias urbanísticas - en cuanto que impone cierto nivel de concreción en la redacción del plan; la necesidad de motivar la solución urbanística escogida, fundamentalmente a través de la memoria de ordenación; el control ciudadano, a través de la formulación de alegaciones en las diversas fases de redacción, o el control de las Comunidades Autónomas. Por otra parte, no puede obviarse el papel limitador de la discrecionalidad del planificador municipal que desarrollan los planes de ordenación del territorio y los planes sectoriales -autonómicos o estatales ${ }^{-71}$.

Así pues, los principios generales desarrollan un papel importante como instrumento de control de la discrecionalidad del planificador. Particularmente relevante es, en este punto, el principio de interdicción de la arbitrariedad según lo ha manifestado nuestro Tribunal Supremo, que, al respecto, ha afirmado: "La potestad de planeamiento tanto si se actúa ex novo como por vía de reforma tiene importantísimos aspectos discrecionales -Sentencia de 11 de julio de 1987-. Pero tal potestad discrecional, en cuanto atribuida por una norma informada por los principios generales del Derecho-art. 1. ,4 4 del Código Civil-, ha de actuarse con sujeción a dichos principios; muy destacadamente ha de recordarse en este sentido el de la interdicción de la arbitrariedad de los poderes públicos -art. 9. „,3 de la Constitución -, lo que en definitiva significa que una irracionalidad en las determinaciones del Plan debe dar lugar a su anulación."

En esta función, el principio de interdicción de la arbitrariedad se vincula a la técnica del control de los hechos determinantes como técnica de control de la discrecionalidad del planeamiento, en tanto en cuanto dicho principio se erige en pauta a la luz de la cuál examinar si la decisión administrativa discrecional reflejada en el planeamiento es acorde a los presupuestos fácticos que le han de servir de soporte. En este sentido, ha afirmado reiteradamente la jurisprudencia, en alusión a las fórmulas de control jurisdiccional de los aspectos discrecionales del planeamiento urbanístico, que "Ia revisión jurisdiccional de la actuación administrativa se extenderá, en primer lugar, a la verificación de la realidad de los hechos, para, en segundo tér-

${ }^{71}$ Sobre las formas de control de la discrecionalidad del planeamiento urbanístico, vid. DELGADO BARRIO, Javier (1993); PONCE SOLÉ, Julio (1996) y DESDENTADO DAROCA, Eva (1999).

${ }^{72}$ STS de 21 de diciembre de 1987 (RJ 1987/9687). 
mino, valorar si la decisión planificadora discrecional guarda coherencia lógica con aquéllos, de suerte que cuando sea clara la incongruencia o discordancia de la solución elegida con la realidad que es su presupuesto inexorable, tal decisión resultará viciada por infringir el ordenamiento jurídico y más concretamente el principio de interdicción de la arbitrariedad de los poderes públicos -art. 9. ', 3 de la Constitución-, que en lo que ahora importa, aspira a evitar que se traspasen los límites racionales de la discrecionalidad y se convierta ésta en causa de decisiones desprovistas de justificación fáctica alguna. ${ }^{, 73}$

Asimismo, el principio de proporcionalidad también constituye una fórmula importante de control de la discrecionalidad del planeamiento. Así lo demuestra la abundante jurisprudencia del Tribunal Supremo que suele citarse sobre el control de la relación medio-fin y de la ponderación administrativa de los intereses implicados en el ejercicio de la potestad de planificación urbanística. ${ }^{74}$ Igualmente, los Tribunales Superiores de Justicia han reconocido en pronunciamientos más recientes la función de límite de la discrecionalidad del planificador que cumple el principio de proporcionalidad. ${ }^{75}$

El principio de desarrollo urbano sostenible, en cuanto que identifica un modelo de ciudad, constituye también, evidentemente, un parámetro a tener muy en cuenta por el planificador urbanístico. En esta línea, el Ministerio de la Vivienda adoptó en el año 2010 el denominado "Libro Blanco de la Sostenibilidad en el Planeamiento Urbanístico Español”, un instrumento que identifica una serie de

${ }^{73}$ Entre otras, SSTS de 11 de julio de 1987 (RJ 1987 /6877) y de 1 de diciembre de 1986 (RJ $1987 / 417)$.

74 Sobre el control judicial de la relación medio-fin, SSTS de 11 de julio de 1987 (RJ 1987/6877), de 21 de diciembre de 1987 (RJ 1987/9687), de 17 de julio de 1989 (RJ 1989/5821), de 30 de junio de 1989 (RJ 1989/4936), y de 29 de noviembre de 1989 (RJ 1989/8371). Sobre el control judicial de la ponderación administrativa de los intereses implicados, SSTS de 1 de diciembre de 1986 (RJ 1987/417), de 27 de febrero de 1987 (RJ 1987/3378), de 4 de abril de 1990 (RJ 1990/3587), de 6 de junio de 1990 (RJ 1990/4806) y de 18 de marzo de 1992 (RJ 1992/3375). En relación con todas estas sentencias, vid. los comentarios que a las mismas se hacen en PONCE SOLÉ, Julio (1996): 201-212, y SÁNCHEZ GOYANES, Enrique (2004): "El Estatuto Jurídico de la Propiedad: Articulación Legal en la obra colectiva Derecho Urbanístico de Andalucía”, El Consultor de los Ayuntamientos y de los Juzgados, Madrid, págs. 134-135.

${ }^{75}$ En la STSJ de la Comunidad Valenciana de 18 de julio de 2002 (JUR 2003/77400) el Tribunal atiende al principio de proporcionalidad, en su vertiente de balance coste-beneficio, para determinar la corrección o incorrección de una modificación puntual del Plan General de Ordenación Urbana de Valencia, que tuvo por objeto el cambio de calificación de una parcela (de uso terciario a residencial). La Sala, tras analizar la solución urbanística adoptada desde la óptica de aquella ecuación, concluye que no se ha acreditado la incorrección de la misma, por lo que desestima el recurso y confirma la actividad administrativa impugnada. 
criterios de sostenibilidad - acordes al modelo de ciudad compacta- referidos al planeamiento urbanístico y que analiza el grado de cumplimiento de los mismos por la legislación de las distintas Comunidades Autónomas. El Libro Blanco tiene carácter meramente indicativo u orientador, pero, desde luego, resulta un instrumento útil para precisar el sentido de ese concepto jurídico indeterminado que es el de desarrollo urbano sostenible, al menos en su aplicación al planeamiento urbanístico.

Pero, más allá de su utilidad como criterio orientador, el concepto de desarrollo urbano sostenible es ya, como se ha indicado antes, un principio jurídico que condiciona las políticas de suelo y, particularmente, el contenido de los instrumentos de ordenación urbanística. Así lo ha puesto de manifiesto la STSJ de Andalucía de 4 de junio de 2009 (RJCA 2009/816), que declaró contraria a derecho una innovación del Plan General de Ordenación Urbanística de Sevilla que suponía la reducción de un parque público, aduciendo, junto a otras razones, su contradicción con el principio de desarrollo urbano sostenible. ${ }^{76}$

Distinta solución recoge la STSJ de Cataluña, de 29 de abril de 2004 (JUR 2004/194714). En este caso, la actividad impugnada consistía en una Resolución del Pleno del Ayuntamiento de Lloret de Mar que, entre otros pronunciamientos, declaraba la pérdida de los derechos a tramitar y ejecutar el Plan Parcial de un Sector y, de conformidad con ello, denegaba "pro futuro" la aprobación de todo instrumento contrario a ese nuevo régimen instaurado (el de la pérdida de aquel derecho). Ello, como consecuencia del incumplimiento por los propietarios de los plazos marcados por el planeamiento general para tramitar el Plan Parcial en cuestión. La Sala resolvió que esta decisión no superaba el juicio de proporcionalidad pues, siendo varios los medios que el ordenamiento jurídico ponía a disposición de la Administración para reaccionar frente al referido incumplimiento, era claro que el adoptado no era el menos restrictivo para los propietarios.

Por último, la STSJ del País Vasco de 18 de mayo de 2006 (RJCA 2007/253) anula un Plan especial de reforma interior que imponía a un particular una servidumbre de paso para solucionar el acceso a un garaje. La Sala, tras efectuar el juicio de proporcionalidad con mención explícita a los tres criterios que, según la doctrina alemana, definen este principio, determina que la solución adoptaba no es la menos onerosa de las posibles para el particular afectado por la servidumbre (cabía otra que no implicaba sacrificio de su propiedad) por la que anula el Plan.

${ }^{76}$ Así, la sentencia señala en el fundamento jurídico decimocuarto lo siguiente: "Efectivamente la limitación, segregación y reducción de un parque público supone desde el prisma óptico medio ambiental, del que no puede separarse en base al principio de integración, el desarrollo sostenible de la actividad planificadora, la segregación, limitación y reducción de una zona verde. Si con anterioridad se ha afirmado la irracionalidad de la calificación de la revisión del plan, por vulnerar los preceptos urbanísticos y no superar el control de los hechos determinantes, a ello debe añadirse, que la limitación del parque como zona verde, supone añadir un plus de irracionalidad e incoherencia a la revisión impugnada. El desarrollo sostenible y el principio de integración en materia urbanística exigen que la opción urbanística elegida, ha de ser la más coherente y racional, con los indicados principios que rigen la materia urbanística y medioambiental, y en el supuesto presente ha de reiterarse que al existir diferentes opciones de ubicación de la edificación, la opción elegida queda lejos de ser la más coherente y racional en el espacio urbanístico y en el medio ambiental." 
Singular trascendencia ha de reconocerse también, como pauta a considerar en el ejercicio de la potestad discrecional de planificación urbanística, al principio de igualdad, que domina toda la regulación del uso del suelo. En este sentido, debe tenerse presente que el propio artículo 1 del Texto Refundido de la Ley del Suelo de 2008 afirma que el objeto de la Ley es precisamente regular "las condiciones básicas que garantizan la igualdad en el ejercicio de los derechos y en el cumplimiento de los deberes constitucionales relacionados con el suelo en todo el territorio estatal". Este enunciado general se concreta en la Ley mediante la inclusión de una serie de cláusulas que refieren determinados aspectos o dimensiones del principio, como la accesibilidad universal (artículos 4.b.) 10.1.c.), la igualdad de trato y de oportunidades a mujeres y hombres (artículos 2.2 y 10.1c.), el acceso en condiciones no discriminatorias a las dotaciones públicas y equipamientos (artículo 4.b.) y las reservas de viviendas sujetas a un régimen de protección pública (artículo 10.1.b.)

Debe señalarse, no obstante, que la virtualidad que tiene el principio de igualdad en este ámbito no siempre ha sido reconocida, tal y como apunta PONCE SOLÉ 77 . Para el autor, sin embargo, la aplicación de este principio a la ordenación urbanística se manifiesta, de una parte, en la prohibición de reservas de dispensación incorporadas en nuestras leyes urbanísticas, que vendrían a ser una aplicación del principio de inderogabilidad de las disposiciones generales administrativas, en el que a su vez late el de igualdad. Se prohíbe, así, en virtud de este principio, la introducción en el planeamiento urbanístico de ordenaciones singulares en beneficio de determinados propietarios ${ }^{78}$. De otra parte, el principio de igualdad se manifiesta en la necesidad de que la atribución de calificaciones urbanística diversas a los terrenos del municipio esté suficientemente fundamen-

77 PONCE SOLÉ, Julio (1996): 215 y 218.

${ }^{78}$ Así, la STS de 25 de mayo de 2009 (RJ 2009/6364) afirma que es doctrina consolidada del Tribunal Supremo "la que proscribe, por incurrir en reserva de dispensación e infracción del principio de igualdad, el establecimiento en el Plan de ordenaciones singulares o especiales que sólo benefician a determinados propietarios en detrimento de los demás y no se amparan en finalidades de interés público. Y a lo anterior añade que "tal es el caso que ahora nos ocupa, pues, como acertadamente apunta la sentencia de instancia, la modificación puntual impugnada no respondía a una finalidad de interés público (nada se ha alegado ni justificado realmente en tal sentido) sino exclusivamente privado, al establecerse a través de la misma una ordenación singular y privilegiada para una concreta finca, diferente de la aplicable a las demás parcelas del mismo ámbito; con lo que se incurrió en desigualdad y arbitrariedad, al configurarse una excepción que produce el efecto, limitado al terreno de propiedad de la promotora beneficiaria de la modificación puntual, de reducir la exigencia de parcela mínima por vivienda e incrementar su aprovechamiento, con un tratamiento singularizado que carece de justificación por no admitirse para los demás solares y no haberse explicado satisfactoriamente las hipotéticas razones de interés público que pudieran sostener ese tratamiento diferenciado. Ni una sola razón se da que justifique la conveniencia para el interés público de variar la norma originaria del Plan Parcial. 
tada, como vía de interdicción de la discriminación. ${ }^{79}$ Por lo demás, la jurisprudencia ha utilizado con frecuencia el principio de igualdad como técnica de control jurisdiccional de la discrecionalidad del planeamiento urbanístico ${ }^{80}$.

Pero sin duda, el aspecto en el que más se deja sentir el principio de igualdad, dentro del ámbito del urbanismo, es en el de la distribución de beneficios y cargas derivados del planeamiento urbanístico. Como señala la STS de 11 de octubre de 2011 (JUR 2011/373337), el principio de equidistribución de beneficios y cargas del planeamiento entre los afectados constituye una manifestación del derecho de igualdad reconocido en el artículo 14 de la Constitución, que ha sido configurada como principio general rector del urbanismo. La articulación de técnicas de equidistribución de beneficios y cargas surge, pues, del reconocimiento de la esencial desigualdad que deriva de la ordenación urbanística y, concretamente, de la diversa clasificación y calificación que atribuyen los planes a los suelos incluidos en su ámbito de ejecución.

El principio de equidistribución de beneficios y cargas, en cuanto que se encuentra en la base de los instrumentos que tienden a posibilitar la igualdad en el disfrute de las facultades inherentes al derecho de propiedad, está presente en la regulación contenida en el Texto Refundido de la Ley del Suelo de 2008. Concretamente, se refieren a él -desde la perspectiva de instrumento de la igualdadlos artículos 8.3.c; 8.5.c; 9.4 y 5; y 35.b de dicho texto legal. Los primeros (artículos 8 y 9) reconocen el derecho de los propietarios a participar en la ejecución de actuaciones de urbanización "en un régimen de equitativa distribución de beneficios y cargas entre todos los propietarios afectados en proporción a su aportación." Por su parte, el artículo 35.b regula como supuesto indemnizatorio "las vinculaciones y limitaciones singulares que excedan de los deberes legalmente establecidos respecto de construcciones y edificaciones, o lleven consigo una restricción de la edificabilidad o el uso que no sea susceptible de distribución equitativa". Este último precepto considera, pues, indemnizables las vin-

79 PONCE SOLÉ, Julio (1996): 216-217.

${ }^{80}$ Así por ejemplo, la STS de 21 de septiembre de 1993 (RJ 1993/6623), que entiende discriminatoria la decisión de un plan de otorgar, sin justificación suficiente, un trato diferenciado a un teatro respecto de los restantes de la ciudad; la STS de 15 de noviembre de 1995 (RJ 1995/8549), que estima carente de una justificación razonable la distinta calificación que otorga un plan a una parcela respecto de las situadas en el entorno inmediato (por lo que ha de reputarse discriminatoria la decisión del plan) ; y la STS de 8 de junio de 1998 (RJ 1998/4390) que igualmente entiende discriminatorio - por injustificado- el tratamiento dado a una finca en suelo urbano, por la mayor intensidad de la afección a un equipamiento en relación con las colindadantes (vid. PONCE SOLÉ, Julio (1996): 223-224 y SÁNCHEZ GOYANES, Enrique (2004): 136-137. 
culaciones y limitaciones que, por singularizarse en un concreto propietario -y no ser susceptibles, por tanto, de equidistribución- colocan a éste en una situación de desigualdad en relación con otros.

Las técnicas de equidistribución, como mecanismos tendentes a corregir la desigualdad derivada de la ordenación urbanística, surgen en un primer momento en el marco de la gestión urbanística, si bien posteriormente el uso de las mismas se extiende a la fase de planeamiento. ${ }^{81}$ De esta manera, las leyes urbanísticas definen en la actualidad una serie de técnicas que operan en el momento de redacción de los planes y otras que lo hacen en el momento de su ejecución. Entre las primeras destacan la delimitación de áreas de reparto y la fijación, por relación a las mismas, de un aprovechamiento medio o tipo que garantiza la equiparación de todos los propietarios incluidos en ellas -con independencia del uso al que se destinen los suelos de su propiedad- a los efectos de atribución de derechos y obligaciones urbanísticos. Entre las segundas, la técnica por antonomasia es la reparcelación, mediante la cual se concretiza el reparto equitativo de beneficios y cargas en el seno de ámbitos considerados idóneos para la ejecución del planeamiento urbanístico, las unidades de ejecución.

Respecto de esta técnica de gestión urbanística -la reparcelación- el principio de proporcionalidad constituye también un elemento capital de su configuración y desarrollo, siendo así que, como afirma el propio Texto Refundido de la Ley del Suelo y disponen las diversas leyes urbanísticas autonómicas, una de las premisas a que ha de sujetarse la distribución de cargas que se realiza mediante el instrumento reparcelatorio, es que la atribución de estas cargas u obligaciones a los propietarios se realice "en proporción" a sus derechos; proporcionalidad que, a su vez, es garantía de igualdad en el tratamiento de todos los propietarios afectados por la operación reparcelatoria.

\section{B) Disciplina urbanística}

$\mathrm{Si}$, según se ha visto, los principios generales desempeñan una función fundamental como pautas o criterios ordenadores de las actividades de planeamiento y gestión urbanística, no menos importante es su papel de delimitación del ejercicio de las potestades de disciplina urbanística.

${ }^{81}$ En este sentido, la precitada STS de 11 de octubre de 2011 (JUR 2011/373337) afirma que el principio de equidistribución es "de aplicación tanto en la redacción de los planes en que se ejercita la potestad de planeamiento, como en la fase posterior de ejecución". 
A este respecto, los principios jurídicos se hallan en la base de determinadas instituciones de derecho sancionador urbanístico, que lógicamente se rige en sus elementos capitales por las mismas reglas que el derecho administrativo sancionador en general. Nos referimos a la prescripción de las infracciones y sanciones, que es expresión del principio de seguridad jurídica; y a la obligación de guardar la debida proporcionalidad en la imposición de sanciones (artículo 131 de la Ley de Procedimiento Administrativo).

Pero sin perjuicio de lo anterior, ha de destacarse la ahora especial incidencia de los principios en el funcionamiento de la actividad de restablecimiento de la legalidad urbanística.

Así, en primer término, son razones de seguridad jurídica las que determinan que la Administración no conserve sine die la posibilidad de actuar frente a actuaciones urbanísticas ilegales ${ }^{82}$, sujetándose el ejercicio de las acciones de restablecimiento a unos plazos de caducidad que determinan las normas urbanísticas. Esta regla encuentra su excepción, sin embargo, en determinados supuestos que las normas urbanísticas consideran especialmente graves, en relación con los cuales entiende el legislador que la legalidad debe primar sobre la seguridad jurídica, y respecto de los que, por tanto, aquella limitación temporal no opera. Tales supuestos de especial gravedad han sido tradicionalmente la realización de actos de edificación o uso del suelo en zonas calificadas como zonas libres y espacios libres y en suelo no urbanizable de especial protección ${ }^{83}$.

82 En este sentido, como señala MELLADO RUIZ, incluso en los casos en los que concurre una ilegalidad tanto formal como material "se impone matizar las posibles consecuencias de normativas desde el criterio central de la seguridad jurídica. $Y$ es que la habilitación administrativa para el restablecimiento de la legalidady la reposición del orden jurídico y fáctico perturbado no debe ser ilimitada tampoco en el tiempo (salvo supuestos excepcionales), pues, con independencia de su ilegalidad urbanística, las obras, una vez consumadas, dan origen a relaciones y situaciones jurídico-civiles, cuya realidad y régimen no puede dejarse en situación permanente de pendencia e inseguridad" (MELLADO RUIZ, Lorenzo (2012): "Reflexiones críticas sobre el nuevo régimen andaluz de edificaciones y asentamientos en suelo no urbanizable: el problema de las viviendas alegales", Práctica Urbanística n ${ }^{\circ} 117$ (edición digital, pág. 6).

83 Supuestos recogidos en el artículo 188.1 del Texto Refundido de la Ley del Suelo de 1976 (salvo el del suelo no urbanizable de especial protección) y en el artículo 255.1 del Texto Refundido de 1992. Estos supuestos han sido recogidos por las leyes autonómicas, que, por lo demás, han añadido, según los casos, otros respecto de los que tampoco rige la limitación temporal, como los consistentes en realizar actos de edificación o uso del suelo en dominio público (particularmente en dominio público marítimo terrestre) o que afecten a bienes catalogados. 
Que la limitación temporal a que se está haciendo referencia es expresión del principio de seguridad jurídica ha sido puesto de manifiesto por pronunciamientos de nuestros tribunales. ${ }^{84}$ Seguridad jurídica en el sentido de estabilidad de las relaciones que se constituyen entre Administración y ciudadanos, aunque en algunos casos, como en éste, lo sea por la vía de los hechos consumados.

En segundo lugar, los principios de buena fe y confianza legítima son los que justifican que los particulares que desarrollan actuaciones urbanísticas al amparo de títulos administrativos que después son anulados, deban ser indemnizados en el caso de que, como consecuencia de dicha anulación, se proceda a demolerlas o dejarlas sin efecto; supuesto indemnizatorio que se contempla actualmente en el artículo 35.d del Texto Refundido de la Ley del Suelo ${ }^{85}$, cuyo tenor es el siguiente:

"Dan lugar en todo caso a derecho de indemnización las lesiones en los bienes y derechos que resulten de los siguientes supuestos:

\section{(...)}

d. La anulación de los títulos administrativos habilitantes de obras y actividades, así como la demora injustificada en su otorgamiento y su denegación improcedente. En ningún caso habrá lugar a indemnización si existe dolo, culpa o negligencia graves imputables al perjudicado."

Como decimos, este supuesto indemnizatorio se apoya en el valor de la confianza. Confianza inducida al particular por una acción administrativa con apariencia de legalidad -la concesión de la licencia- que le mueve a desarrollar la actuación urbanística en la creencia de que la misma se ajusta a Derecho ${ }^{86}$.

${ }^{84}$ En este sentido SSTSJ de Aragón de 28 de octubre de 2002 (JUR 2003/133015), y de 20 de julio de 2004 (JUR 2005/52632) y STSJ de Galicia de 10 de mayo de 2001 (JUR 2001/234860).

${ }^{85}$ En este sentido, REVUELTA PÉREZ y NARBÓN LAÍNEZ han afirmado que el reconocimiento legal de la responsabilidad patrimonial en estos casos es una manifestación del principio de confianza legítima (REVUELTA PÉREZ, Inmaculada y NARBÓN LAÍNEZ, Edilberto (2010): "Ejecución de sentencias en materia urbanística, demolición y terceros de buena fe. El caso de la anulación de licencias", Revista Crítica de Derecho Inmobiliario 720, pág. 1613).

${ }^{86}$ En este sentido, BELADÍEZ ROJO señala que "Por el simple hecho de existir la licencia, la Administración ha creado la apariencia de un derecho, que ha hecho surgir en el titular de la misma la legítima creencia de haberlo adquirido (salvo, claro está, que medie dolo o negligencia grave por parte del titular)"(BELADÍEZ ROJO, Margarita (1995): "Los vicios de los actos urbanísticos y su revisión”, Revista de Administración Pública 138, pág. 158). 
El mismo fundamento se halla en la base del artículo 51, apartado segundo, también del Texto Refundido de la Ley del Suelo, que impone a la Administración la obligación de indemnizar al adquirente de buena fe, a título de responsabilidad patrimonial, de los perjuicios que sufra como consecuencia de la omisión de la resolución por la que se acuerde la práctica de la anotación preventiva del inicio de un expediente de disciplina urbanística. Así, dispone este precepto:

"En todo caso, en la incoación de expedientes de disciplina urbanística que afecten a actuaciones por virtud de las cuales se lleve a cabo la creación de nuevas fincas registrales por vía de parcelación, reparcelación en cualquiera de sus modalidades, declaración de obra nueva o constitución de régimen de propiedad horizontal, la Administración estará obligada a acordar la práctica en el Registro de la Propiedad de la anotación preventiva a que se refiere el artículo 53.2.

La omisión de la resolución por la que se acuerde la práctica de esta anotación preventiva dará lugar a la responsabilidad de la Administración competente en el caso de que se produzcan perjuicios económicos al adquirente de buena fe de la finca afectada por el expediente. En tal caso, la citada Administración deberá indemnizar al adquirente de buena fe los daños y perjuicios causados."

Sin perjuicio de lo anterior, en los casos en los que es la propia Administración autora de la licencia la que pretende su revisión, han de tomarse en consideración los límites que le impone el artículo 106 de la Ley de Procedimiento Administrativa a su facultad de revisión de los actos administrativos, entre los que se encuentra la consideración del principio de buena $\mathrm{fe}^{87}$. En este sentido, es posible que en atención a ello la Administración no decida anular la licencia e indemnizar al particular, sino mantenerla en vigor. Habrá de estarse en todo caso a lo que resulte de la ponderación de los intereses públicos y privados en conflicto y demás circunstancias concurrentes.

Otro ámbito o aspecto de la potestad de restablecimiento de la legalidad urbanística en la que el que los principios juegan un papel destacado es en el de la elección y ejecución de las concretas medidas de reposición de la realidad física alterada.

${ }^{87}$ A este respecto, BELADÍEZ ROJO señala, en relación con las licencias viciadas de nulidad de pleno derecho que "la Administración puede poner en marcha el mecanismo previsto en el artículo 102 de la LAP y revisar, de oficio o a instancia de los particulares, los actos que incurran en la infracción tipificada en el citado artículo 211. De ahi que si se da esta circunstancia, deberá iniciar un procedimiento de revisar de oficio; procedimiento que podrá iniciarlo en cualquier momento - sin perjuicio de que al mismo le sean aplicables los imprecisos límites a la revisión que contiene el artículo 106 de la LAP-” (BELADÍEZ ROJO, Margarita (1995):172). En esta línea, vid., asimismo, la STS de 29 de noviembre de 2005 (RJ 2006/1163). 
La potestad de protección de la legalidad urbanística es esencialmente regla$\mathrm{da}^{88}$. Ello puede hacer pensar que en lo que se refiere a la adopción de medidas reparadoras del orden jurídico-administrativo infringido la Administración no dispone de margen de apreciación alguno y que, por tanto, el juego de los principios generales en este ámbito es muy limitado ${ }^{89}$.

Tal afirmación resulta, no obstante, discutible, pues es difícil que las disposiciones urbanísticas prevean todas las medidas adecuadas de reintegración de la ordenación urbanística infringida, habida cuenta del extraordinario casuismo existente en este ámbito. De ahí que desde la doctrina se haya defendido el carácter no tasado de las medidas reparadoras de la legalidad urbanística y, consecuentemente, se haya atribuido a la Administración la facultad de configurar según cada caso, con base en los principios jurídicos, particularmente el de proporcionalidad, las medidas más adecuadas a la finalidad reintegradora ${ }^{90}$, es decir, de elegir de entre las varias medidas idóneas para la consecución del fin de restablecimiento de la legalidad, aquélla que resulte menos restrictiva para los intereses del particular ${ }^{91}$.

${ }^{88}$ La STS de 24 de febrero de 1997 (RJ 1997/1289) señala que "las competencias que en materia urbanística el TRLS confiere a los Ayuntamientos son, por regla general, regladas, y desde luego lo son las destinadas a restablecer la legalidad urbanística. Quiere decirse con ello que, cuando se den los presupuestos de a los que el ordenamiento anuda una consecuencia jurídica, el Ayuntamiento no puede obviarla en función de consideraciones discrecionales de política urbanística".

${ }^{89}$ En esta línea, se ha sostenido por la jurisprudencia que "en los casos de actuaciones contrarias al planeamiento urbanístico es imprescindible restaurar la realidad fisica alterada o transformada por la acción ilegal, de manera que no existe la posibilidad de optar entre dos o más medios distintos y no es, por tanto, aplicable el principio de proporcionalidad". (SSTS de 28 de marzo de 2006, RJ 2006/3225; de 28 de abril de 2000, RJ 2000/4953; de 15 de octubre de 2001, RJ 2001/8285; de 21 de octubre de 2001, RJ 2001/8302; y de 2 de octubre de 2002, RJ 2002/8858).

${ }^{90}$ En este sentido vid. GARCÍA DE ENTERRÍA, Eduardo. y PAREJO ALFONSO, Luciano (1981): "Lecciones de derecho Urbanístico", 1ª ed. Civitas, Madrid, págs. 351 y ss. Los autores, tras negar el carácter taxativo de las medidas protectoras de la legalidad urbanística recogidos en la Ley del Suelo de 1976 -que se limitaban a la demolición y el impedimento de usos ilegales- sostienen que "a la Administración le está autorizado configurar las medidas más adecuadas a la finalidad protectora y reintegradora aludida bastantes a la misma. Así lo imponen, a nuestro juicio, los principios generales de congruencia y proporcionalidad, básicos, como sabemos, en toda la materia de intervención de la actividad urbanística".

${ }^{91}$ Esta idea de que en el ámbito de la protección de la legalidad urbanística sí puede darse la situación en que la Administración deba optar entre varias medidas idóneas ha sido sustentada por la doctrina con base en la STS de 18 de febrero de 1992 (RJ 1992/2904). Esta sentencia, dictada en relación con un supuesto de ejecución de obras ilegales, señala que "el principio de proporcionalidad, en lo que ahora importa, opera en dos tipos de supuestos: 
En cualquier caso, la imposibilidad de optar entre dos o más medios distintos de restablecimiento de la legalidad urbanística no excluiría absolutamente que los principios del derecho puedan tener alguna incidencia en este ámbito pues, en tal sentido, indica la STS de 18 de mayo de 1992 (RJ 1992/2904) que el principio de proporcionalidad opera, con carácter excepcional, y en conexión con los principios de buena fe y equidad, también en aquellos casos en los que existe un único medio de actuación, pero que resulta inadecuado y excesivo en relación con el caso concreto $^{92}$. De este modo, los referidos principios operarían como una regla de modulación de la aplicación estricta de la norma jurídica, con la finalidad de evitar consecuencias desproporcionadas en relación con las circunstancias concurrentes.

Especial importancia se ha reconocido a este respecto al principio de proporcionalidad -también denominado en este ámbito "menor demolición"-. Así, la doctrina ha sistematizado, a partir de los pronunciamientos jurisprudenciales existentes sobre la cuestión, los supuestos en los que el principio de proporcionalidad actúa minorando las consecuencias de la adopción de la medida de reparación del orden jurídico perturbado que puede considerarse extrema: la demolición. ${ }^{93}$

Los supuestos comúnmente aceptados son los siguientes ${ }^{94}$ :

A) Con carácter ordinario, en aquellos casos en los que el ordenamiento jurídico admite la posibilidad de elegir uno entre varios medios utilizables.

B) Ya con carácter excepcional y en conexión con los principios de buena fe y equidad, en los supuestos en los que aun existiendo en principio un único medio éste resulta a todas luces inadecuado y excesivo en relación con las características del caso contemplado." A este respecto, vid. ARREDONDO GUTIÉRREZ, José Manuel (2009): "Demolición de edificaciones ilegales y protección de la legalidad urbanística", $3^{\mathrm{a}}$ ed., Comares, Granada, págs. 32-42 y CORRAL GARCÍA, Esteban (1997): "La protección de la legalidad urbanística y la Sentencia del Tribunal Constitucional 61/1997. Situación legal actual", El consultor de los Ayuntamientos y de los Juzgados 23, tomo II, págs. 3530 y ss.

92 Vid. cita anterior.

93 A este respecto, se ha afirmado que "la demolición de lo construido al tratarse de medida de excepción y extrema ha de ser aplicada mediante una interpretación de las normas lo más restrictiva posible para no quebrantar la regla de la proporcionalidad entre los medios a emplear y los objetivos a conseguir y únicamente puede estimarse procedente cuando se hayan infringido normas urbanísticas que impidan la legalización de las obras o su mantenimiento implique un daño irreparable o de dificil reparación." [SSTS de 24 de octubre de 1986 (RJ 1986/7709) y de 29 de septiembre de 2008 (RJ 2008/7440)].

${ }^{94}$ En este sentido, vid ARREDONDO GUTIÉRREZ, José Manuel (2009): 36-40; PAYÁ GASENT, Josep Antoni (1989): "La demolición en las infracciones urbanísticas: Aproximación a los criterios de la jurisprudencia en la aplicación del principio de proporcionalidad", Revista de Derecho Urbanístico 99, págs. 77-90, y RODRÍGUEZ FERNÁNDEZ, Ignacio (2009): "Demolición de 
- Obras extralimitadas que se amparan sólo parcialmente en la licencia concedida. En estos casos, habrá de evitarse la demolición de la parte de la obra que sí está amparada en la licencia ${ }^{95}$.

- Escasa entidad de la ilegalidad cometida. En este caso, la aplicación del principio de proporcionalidad conduce a la evitación de la demolición de las irregularidades no sustanciales existentes en la construcción, en virtud de la aceptación de ciertos márgenes de tolerancia de errores en la actividad constructiva $^{96}$.

Por último, el principio de buena fe - concretamente la condición de tercer adquirente de la buena $\mathrm{fe}^{-}$ha sido frecuentemente invocado en el ámbito de la ejecución de sentencias que ordenan la demolición de viviendas.

A este respecto, es preciso señalar que, según la jurisprudencia del Tribunal Supremo, la presencia de terceros adquirentes no constituye una circunstancia que justifique, en general, un pronunciamiento de imposibilidad de ejecutar una sentencia que declare la ilegalidad de una edificación ${ }^{97}$. Afirma, en este sentido, el al-

obras ilegales, restablecimiento de la legalidad y tutela judicial efectiva. Reflexiones a propósito de la Sentencia del Tribunal Constitucional 22/2009, de 26 de marzo", Revista General de Derecho Administrativo 22 (edición digital) págs 26-27.

Además de los generalmente aceptados, ARREDONDO GUTIÉRREZ y PAYÁ GASENT identifican como supuesto de aplicación del principio de proporcionalidad las situaciones que se han desarrollado y consolidado de facto como consecuencia de la falta de diligencia de la Administración en sus funciones de vigilancia. PAYÁ GASENT añade otras circunstancias que vendrían a conformar la aplicación del principio de proporcionalidad:

- El estado de construcción, y especialmente la cuantificación de los costos de las obras adicionales que supondría la demolición del elemento objeto de la infracción.

- La presencia de terceros adquirentes de buena fe, como circunstancia que agrava y amplía las consecuencias dañosas inherentes a toda demolición.

Vid. ARREDONDO GUTIÉRREZ, José Manuel (2009): 41-42 y PAYÁ GASENT, Josep Antoni (1989): 89-90.

${ }^{95}$ Vid. por ejemplo, la STSJ de Andalucía, de 4 de febrero de 1991, aceptada por la STS de 22 de noviembre de 1994 (RJ 1994/8644), que versan sobre la demolición del exceso de altura de una planta ático.

96 Vid. entre otras, la STS de 18 de julio de 1995 (RJ 1995/6172), en la que se decide el mantenimiento de una factoría situada en las afueras de una ciudad sobre la base de la idea de que, en virtud del principio de proporcionalidad, "no procederá la demolición en los casos en que se esté ante desajustes minimos con la normativa urbanistica de la construcción ilegal".

${ }^{97} \mathrm{El}$ Tribunal Supremo sostiene que "la condición de terceros adquirentes de buena fe carece de trascendencia a los efectos de impedir la ejecución de una sentencia que impone la demolición del inmueble de su propiedad por 
to tribunal, que el artículo 34 de la Ley Hipotecaria no protege a los terceros adquirentes frente a la demolición -según la doctrina jurisprudencial, este precepto tutela el derecho real, pero no la pervivencia de la cosa objeto del mismo, cuando debe desaparecer porque así lo exige el ordenamiento jurídico ${ }^{98}$-, y que existen otros cauces de protección distintos de la inejecución, concretamente la vía de la indemnización, que es la contemplada, según se ha visto, en el artículo 51.2 del Texto Refundido de la Ley del Suelo.

Esta postura ha sido rebatida por un sector de la doctrina científica, que al respecto ha sostenido, por una parte, que en el caso de las construcciones ejecutadas bajo la cobertura de una licencia, el hecho de su inscripción en el Registro de la Propiedad confiere al particular un plus de protección, con base en el valor de la confianza, de suerte que en ese caso - en la medida en que no consten en el Registro procedimientos administrativos de disciplina urbanística ni recursos contencioso-administrativos contra la misma- el artículo 34 de la Ley Hipotecaria debe ampararlo también frente a la demolición ${ }^{99}$. Por otra, que el reconocimiento de un derecho indemnizatorio constituye una vía de protección ciertamente insatisfactoria, pues la obtención de la indemnización comporta para el particular la severa carga de iniciar un expediente administrativo que, con toda seguridad, no se resolverá sino ante los tribunales de justicia muchos años después de la anulación de la licencia y de la demolición de la edificación ${ }^{100}$.

Sea como fuere, se plantea la posibilidad de que el principio de confianza que protege al adquirente de buena fe sea considerado como causa de imposibilidad de ejecutar la sentencia que anule o declare la nulidad de una licencia. No quiere decirse con ello, ni mucho menos, que deba declararse la imposibilidad de ejecución siempre que existan terceros adquirentes de buena fe, pues en muchos casos concurrirán intereses de diversa índole que impedirán el mantenimiento de la edificación (por ejemplo, la protección del medio ambiente o del dominio público). Pero, al menos, sí parece razonable la inclusión de esta variable en el proceso de decisión sobre la ejecución de sentencias que declaran la ilegalidad de una licencia, de manera que la demolición no se imponga como solución automática ${ }^{101}$.

no ajustarse a la legalidad urbanística" (SSTS de 26 de septiembre de 2006, RJ 2006/6665; de 4 de febrero de 2009, RJ 2009/3306; y de 29 de diciembre de 2010, RJ 2011/1066).

${ }^{98}$ SSTS de 4 de febrero de 2009 (RJ 2009/3306) y de 29 de diciembre de 2010 (RJ 2011/1066).

99 Vid. REVUELTA PÉREZ, Inmaculada y NARBÓN LAÍNEZ, Edilberto (2010): 1613

100 Vid. REVUELTA PÉREZ, Inmaculada y NARBÓN LAÍNEZ, Edilberto (2010): 1630-1631.

101 Este planteamiento fue tomado en consideración por nuestro Gobierno cuando se propuso iniciar la tramitación de la Ley 8/2013, de 26 de junio, de Rehabilitación, Regeneración y Reno- 


\section{REFLEXIONES FINALES}

En las páginas anteriores se ha puesto de manifiesto que los principios jurídicos cumplen un papel fundamental en el ordenamiento jurídico-administrativo, en cuanto sector del derecho que precisa especialmente de elementos que sirvan de soporte al complejo entramado de normas en que se estructura, y que lo doten de la necesaria coherencia y unidad. Ese papel es especialmente relevante, como también se ha visto, en el ámbito urbanístico, respecto del cual los principios del derecho, especialmente los que han sido analizados pormenorizadamente en el presente trabajo, pueden coadyuvar a la construcción soluciones jurídicas justas y dotadas de estabilidad y seguridad.

En la actualidad se asiste a un desprestigio de los principios jurídicos, motivado en gran medida por el uso abusivo que se viene realizando de los mismos por los operadores jurídicos. Su naturaleza abierta e inconcreta ha facilitado que la invocación de los principios del derecho como medio para sustentar o, al menos, reforzar argumentaciones jurídicas se haya generalizado hasta límites inapropiados. En este sentido, parece que se han entendido los principios, especialmente en las relaciones contradictorias entre Administración y particular, como un recurso argumentativo último al que siempre se puede acudir cuando no se encuentran otros apoyos jurídicos para sustentar una determinada postura, o, en todo caso, como un elemento que adicionar, a mayor abundamiento, al discurso ya construido.

Este empleo indiscriminado y forzado de los principios jurídicos ha terminado casi por despojarlos de su naturaleza prescriptiva. Sin embargo, los principios obligan, no son -exclusivamente- meros criterios orientadores o interpretativos de cuyo contenido es posible apartarse en todo caso, sino que son verdaderos mandatos jurídicos que se integran en el sistema de fuentes del derecho y que, en

vación Urbanas, que ha modificado de forma sustancial el vigente Texto Refundido de la Ley de Suelo. En este sentido, antes de iniciar propiamente la tramitación de la Ley, el Gobierno puso en circulación un documento-propuesta denominado "Documento de alternativas a favor de la rehabilitación, la regeneración y la renovación urbana" en el que se proponía añadir un nuevo apartado 6 al artículo 19 de la Ley del suelo, en virtud del cual se configuraba como causa de imposibilidad legal de ejecución de sentencias o actos administrativos que impongan la demolición de una edificación, el que la misma sea propiedad, en el momento de la ejecución, de adquirentes que sean considerados de buena fe de conformidad con el artículo 34 de la Ley Hipotecaria, siempre que se cumplan determinadas condiciones (ejecución conforme al proyecto para el que se otorgó la licencia, la ausencia de afecciones al dominio público y al medio ambiente, etc.). El precepto propuesto, no obstante, no fue incorporado finalmente a la referida Ley 8/2013 ni, por tanto, a al Texto Refundido. 
cuanto tales, vinculan a la Comunidad. Además, en el ámbito del derecho administrativo, los principios cumplen la importante función de habilitar y de limitar el ejercicio de potestades por las Administraciones públicas.

La observancia y consideración de los principios son especialmente necesarias en un sector del Derecho, el urbanístico, en el que están comenzando a proliferar fórmulas jurídicas poco satisfactorias por su inestabilidad e insustancialidad. En ese contexto, es preciso recordar la vigencia en este ámbito de los principios jurídicos; principios que por expresar las convicciones ético-jurídicas de la Comunidad, pueden proveer soluciones sustantivas seguras y asumibles por el conjunto de los ciudadanos

A este respecto, el papel que los principios juegan y deben seguir jugando en la formulación y aplicación de las disposiciones urbanísticas es muy importante.

En primer lugar, los principios del Derecho cumplen la función esencial de delimitar una potestad profundamente discrecional como es la de planificación urbanística. En este sentido, en línea con lo afirmado, la consideración de los principios jurídicos en el proceso de elaboración del planeamiento es lo que garantiza que las decisiones que en ejercicio de esta función pública se adopten sean justas, estables y aceptables por la Comunidad. Especial referencia merece en este punto - por su novedad- el principio de desarrollo urbano sostenible, cuya observancia en aquel proceso, en cuanto principio rector de las políticas públicas sobre suelo, permite avanzar hacia la construcción de una ciudad respetuosa con el medio ambiente, eficiente desde un punto de vista económico, y equilibrada en su composición y estructuración social.

En segundo lugar, el respeto a los principios generales del Derecho, particularmente los de igualdad y proporcionalidad, garantizan el justo reparto de los derechos y las obligaciones que derivan del planeamiento urbanístico y que se materializan en su ejecución.

Y en tercer lugar, en el ámbito de la disciplina urbanística, la atención a estos principios - sobre todo a los de proporcionalidad, seguridad jurídica, buena fe y confianza legítima- modulan la configuración normativa y el ejercicio de las potestades de reacción administrativa contra actuaciones urbanísticas ejecutadas en contravención del ordenamiento jurídico, adecuando la regulación y el uso de tales facultades a la importancia real del hecho cometido, a las circunstancias de su realización y a la situación de los titulares de tales actuaciones.

En definitiva, los principios jurídicos son una pieza clave del ordenamiento urbanístico, cuyo respecto y consideración por los órganos responsables de la re- 
gulación y aplicación de sus instituciones dota a éstas de la necesaria estabilidad, seguridad y equilibrio entre los intereses implicados.

\section{BIBLIOGRAFÍA}

ALENZA GARCíA, José Francisco (2010): "Desarrollo Sostenible" en la obra colectiva "Los principios jurídicos del Derecho Administrativo", 1ª ed., La Ley, Madrid.

ARANA GARCíA, Estanislao (2003): "La alegación de la propia torpeza y su aplicación al Derecho Administrativo", Editorial Comares, Granada.

ARREDONDO GUTIÉRREZ, José Manuel (2009) "Demolición de edificaciones ilegales y protección de la legalidad urbanística", $3^{\text {a }}$ ed., Editorial Comares, Granada.

BARNÉS VÁZQUEZ, Javier (1998): "El Principio de proporcionalidad. Estudio Preliminar", Cuadernos de Derecho Público 5.

BARNÉS VÁZQUEZ, Javier (1994): "Introducción al principio de proporcionalidad en el Derecho Comparado y Comunitario", Revista de Administración Pública 135.

BELADÍEZ ROJO, Margarita (2000): La vinculación de la Administración al Derecho, Revista de Administración Pública 153.

BELADÍEZ ROJO, Margarita (1995): "Los vicios de los actos urbanísticos y su revisión", Revista de Administración Pública 138.

BELADÍEZ ROJO, Margarita (1994): "Los principios jurídicos", 1 a edición, Tecnos, Madrid.

BERMEJO VERA, José (2010): "El Principio de seguridad jurídica" en la obra colectiva "Los principios jurídicos del Derecho Administrativo", $1^{\text {a }}$ ed., La Ley, Madrid.

CARLÓN RUIZ, Matilde (2010) "El principio de proporcionalidad", en la obra colectiva, "Los principios jurídicos del Derecho Administrativo", 1ª ed., La Ley, Madrid.

CASTILLO BLANCO, Federico A. (2002): "El principio de seguridad jurídica: especial referencia a la certeza en la creación del derecho", Documentación Administrativa 263-264.

CASTILLO BLANCO, Federico A. (1998): "La protección de la confianza en el Derecho Administrativo", $1^{\text {a }}$ edición, Marcial Pons, Madrid.

CORRAL GARCÍA, Esteban (1997): "La protección de la legalidad urbanística y la Sentencia del Tribunal Constitucional 61/1997. Situación legal actual", El consultor de los Ayuntamientos y de los Juzgados 23, tomo II.

DELGADO BARRIO, J. El control de la discrecionalidad del planeamiento urbanistico, $1^{\mathrm{a}}$ edición, Cuadernos Civitas, Madrid, 1993. 
DESDENTADO DAROCA, Eva (1999): "Discrecionalidad Administrativa y Planeamiento Urbanístico", $2^{a}$ edición, Aranzadi, Navarra.

DESDENTADO DAROCA, Eva (2010): "El principio de interdicción de la arbitrariedad" en la obra colectiva "Los principios jurídicos del Derecho Administrativo", $1^{a}$ ed., La Ley, Madrid.

GARCÍA DE ENTERRÍA, Eduardo (1984): "Principio de legalidad, Estado material de derecho y facultades interpretativas y constructivas de la jurisprudencia en la Constitución", publicado en Revista Española de Derecho Constitucional 10 y en su libro "Reflexiones sobre la Ley y los principios generales del Derecho", Cuadernos Cívitas, Madrid.

GARCÍA DE ENTERRÍA, Eduardo (1963): "Prólogo al libro de Theodor Viehweg «Tópica y Jurisprudencia»", publicado en la Revista de Administración Pública 40 y en su libro "Reflexiones sobre la Ley y los principios generales del Derecho", Cuadernos Cívitas, Madrid.

GARCÍA DE ENTERRÍA, Eduardo (1963): "Reflexiones sobre la Ley y los principios generales del Derecho en el Derecho Administrativo", publicado en la Revista de Administración Pública 40 y en su libro "Reflexiones sobre la Ley y los principios generales del Derecho", Cuadernos Cívitas, Madrid.

GARCÍA DE ENTERRÍA E. y FERNÁNDEZ T.R. Curso de Derecho Administrativo, $I, 13^{\mathrm{a}}$ ed., Thomson-Civitas, Madrid, 2006.

GARCÍA DE ENTERRÍA, Eduardo y PAREJO ALFONSO, Luciano (1981): "Lecciones de derecho Urbanístico", $1^{\mathrm{a}}$ ed. Civitas, Madrid.

GARCÍA LUENGO, Javier (2002): "El principio de protección de la confianza legítima en el Derecho Administrativo", $1^{\text {a }}$ edición, Civitas, Madrid.

HIERRO SÁNCHEZ-PESCADOR, Liborio Luis (1989): "Seguridad jurídica y actuación administrativa", Documentación Administrativa 218-219.

LEGUINA VILLA, Jesús (1987): "Principios generales del Derecho y Constitución", Revista de Administración Pública 114.

LÓPEZ GONZÁLEZ José Ignacio (1988): "El principio general de proporcionalidad en derecho administrativo", $1^{a}$ edición, Instituto García Oviedo, Sevilla.

MARTÍN REBOLLO, Luis (2010): "Sobre los principios generales del derecho. Una reflexión moderadamente crítica" en la obra colectiva "Los principios jurídicos del Derecho Administrativo", $1^{\text {a }}$ ed., La Ley, Madrid.

MARTÍNEZ TAPIA, Ramón (2000): "Igualdad y Razonabilidad en la justicia constitucional española", Universidad de Almería. Servicio de Publicaciones, Almería.

MELLADO RUIZ, Lorenzo (2012): "Reflexiones críticas sobre el nuevo régimen andaluz de edificaciones y asentamientos en suelo no urbanizable: el problema de las viviendas alegales", Práctica Urbanística 117 (edición digital). 
MENÉNDEZ REXACH, Ángel (2003): “Urbanismo sostenible, clasificación del suelo y criterios indemnizatorios: estado de la cuestión y algunas propuestas", Revista de Derecho Urbanístico y Medio Ambiente.

NIETO GARCÍA, Alejandro (2005): "Derecho Administrativo Sancionador", 4 a ed., Tecnos, Madrid.

ORTEGA ÁLVAREZ, Luis (2002): "Los principios generales del derecho" en la obra colectiva "Derecho Administrativo I: Introducción y Ordenamiento Jurídico", $1^{\text {a }}$ edición, Iustel, edición digital, Madrid.

PAREJO ALFONSO, Luciano (1998): Prólogo a la obra de Castillo Blanco "La protección de la confianza en el Derecho Administrativo", $1^{\mathrm{a}}$ edición, Marcial Pons, Madrid.

PAYÁ GASENT, Josep Antoni (1989): "La demolición en las infracciones urbanísticas: Aproximación a los criterios de la jurisprudencia en la aplicación del principio de proporcionalidad", Revista de Derecho Urbanístico 99.

PÉREZ LUÑO, Antonio Enrique (2003): "La seguridad jurídica" en la obra colectiva "Teoría del Derecho y Filosofía del Derecho", 1 edición (digital), Iustel, Madrid.

PIÑAR MAÑAS, José Luis (2003): "El desarrollo sostenible como principio jurídico" en la obra colectiva "Estudios de Derecho Público Económico", 1 ${ }^{\mathrm{a}}$ ed., Civitas, Madrid.

PONCE SOLÉ, Julio (1996): "Discrecionalidad urbanística y autonomía municipal", $1^{\text {a }}$ edición, Civitas, Madrid.

RAMALLO LÓPEZ, Fátima (2011): "El principio de desarrollo urbano sostenible. Un nuevo paradigma en la planificación urbanística", Revista Española de Derecho Administrativo 150.

REBOLLO PUIG, Manuel (2010): "Los principios generales del derecho (atrevimiento atribulado sobre su concepto, funciones e inducción)" en la obra colectiva "Los principios jurídicos del Derecho Administrativo", $1^{\mathrm{a}}$ ed., La Ley, Madrid.

REBOLLO PUIG, Manuel (1991): "Juricidad, legalidad y reserva de Ley como límites de la potestad reglamentaria", Revista de Administración Pública 125.

REVUELTA PÉREZ, Inmaculada y NARBÓN LAÍNEZ, Edilberto (2010): "Ejecución de sentencias en materia urbanística, demolición y terceros de buena fe. El caso de la anulación de licencias", Revista Crítica de Derecho Inmobiliario 720.

RODRÍGUEZ FERNÁNDEZ, Ignacio (2009): "Demolición de obras ilegales, restablecimiento de la legalidad y tutela judicial efectiva. Reflexiones a propósito de la Sentencia del Tribunal Constitucional 22/2009, de 26 de marzo", Revista General de Derecho Administrativo 22 (edición digital). 
RODRÍGUEZ-ARANA MUÑOZ, Jaime (2008): "Los principios generales del Derecho Administrativo en la jurisprudencia administrativa española", Revista Andaluza de Administración Pública 70.

SÁNCHEZ GOYANES, Enrique (2004): "El Estatuto Jurídico de la Propiedad: Articulación Legal en la obra colectiva Derecho Urbanístico de Andalucía”, El Consultor de los Ayuntamientos y de los Juzgados, Madrid.

SANTAMARÍA IBEAS, José Javier (1997): "Los valores superiores en la jurisprudencia del Tribunal Constitucional", Dykinson.

SANTAMARÍA PASTOR, Juan Alfonso (2010) Presentación de la obra colectiva "Los principios jurídicos del Derecho Administrativo" $1^{\text {a }}$ ed., La Ley, Madrid.

SUAY RINCÓN, José (1993): "La doctrina de los principios generales del derecho y su contribución al desarrollo del Derecho Administrativo" en la obra colectiva "La protección jurídica del ciudadano (Procedimiento administrativo y garantía jurisdiccional). Estudios en homenaje al profesor Jesús González Pérez, I", $1^{a}$ ed. Civitas, Madrid.

VERA JURADO, Diego e ILDEFONSO HUERTAS, Rosa (2003): "La ordenación urbanística", en la obra colectiva "Derecho Urbanístico de Andalucía", $1^{a}$ edición, Tirant Lo Blanch, Valencia. 